\title{
A seismological study of shallow weak micro- earthquakes in the urban area of Hamburg city, Germany, and its possible relation to salt dissolution
}

\section{Torsten Dahm, Sebastian Heimann,}

Institute for Geophysics, University of Hamburg, Wilhelm Bialowons, Deutsches Elektron-Synchrotron DESY, Hamburg submitted: August 2009. Revised: July 2010. Final version: November 2010 


\section{Summary}

In the night from 8/9 April 2009, shortly after midnight on Maundy Thursday before Easter, several people in Gross-Flottbek, Hamburg, felt unusual strong ground shocks so that some of them left their houses in fear of earthquake shaking. Police and Fire Brigade received phone calls of worried residents. A few days later Internet pages were published where people reported their observations. On 21 April 2009 at about 8 p.m. local time a second ground shaking event was felt. Damage to buildings or infrastructure did not occur to our knowledge. The Institute of Geophysics, University of Hamburg, installed from 22 April to 17 May 2009 three temporal seismic stations in the epicentral area. Seismological data from two nearby stations at the Deutsches Elektron-Synchrotron (DESY) at $1 \mathrm{~km}$ and the Geophysical Institute at $7 \mathrm{~km}$ distance were collected and integrated to the temporal network.

The events occurred above the roof of the shallow Othmarschen Langenfelde salt diapir (OLD), in an area known for active sinkhole formation and previous historic ground shaking events. The analysis of the seismological data shows that three shallow microearthquakes occurred from 8 to 21 April at a depth of about $100 \mathrm{~m}$, the largest one with a moment magnitude of about $M_{W}$ 0.6. Depth location of such shallow events is difficult with standard methods, and is here constrained by waveform modeling of surface waves. Earthquakes occurring in soft sediments within the uppermost $100 \mathrm{~m}$ are a rare phenomena and cannot be explained by standard models. Rupture process in soft sediments differ from those on faults in more competent rock. We discuss the rupture and source mechanism of the events in the context of previous historic shocks and existing sinkhole and deformation data. Although the event was weak, the rupture duration of 0.3 $s$ was unusual long. Three possible models for the generation of repeated ground shaking events in Gross Flottbek are developed and discussed, implying quit different hazards for subsidence, ground motion and sinkhole formation. Our favored model postulates that roof failure occurs in an existing soil cavity beneath the epicenter at a depth of about $100 \mathrm{~m}$. Other models bearing a smaller geo-hazard cannot be disproved with the data available, but future geophysical experiments may be planned to resolve this question.

Keywords: gypsum karst, subrosion in salt, sinkholes, rock-fall, micro-earthquakes

\section{Introduction and background}

The region of Hamburg has about nine salt diapirs of different shape and depth. The Othmarschen Langenfelde diapir (OLD) lies beneath most of the north-western part of the city of Hamburg and has a total length of about $20 \mathrm{~km}$. It extends in NNE direction up to the small of city Quickborn (Fig.1). The caprocks of the OLD are partly situated 
only few meters below the surface.

Because of the shallowness of the OLD the hazard related to possible gypsum karst and salt dissolution is high. For instance, the long time span of dissolution of salt in the roof of a diapir generates thick layers of residual gypsum and anhydrite caprocks. Such layers are well known for many shallow diapirs (e.g. Gorleben in North Germany, see Klinge et al., 2002), and residual gypsum layers have indeed been probed in some boreholes above the OLD. Gypsum caprock often contains caves or extended karst systems (see Warren, 2006). The gypsum caves in Bad Segeberg, about $60 \mathrm{~km}$ north of Hamburg, have an open length of about $260 \mathrm{~m}$ and pose a good example for gypsum karst. Cave galleries are partly up to $\approx 3 \mathrm{~m}$ high and span over $10 \mathrm{~m}$ or more. Other examples of extended gypsum karst are the caves in the Kyffhäuser mountains in North Thüringen, Germany, the caves Spicole Acquafredda (open length of $10500 \mathrm{~m}$ ) and Grave Gruppo - Valone Calfono Spring (open length of $2830 \mathrm{~m}$ ), both in Calabria, Italy (Parise and Trocino, 2005), or the gypsum karst in Kungur (Russia), the Ukraine, or in Ripon, UK (see Waltham et al., 2005). Surface indicators of gypsum karst are sinkholes or collapse dolines. Dissolution sinkholes are often associated with the slow sediment subrosion at depth into void space or caves. Collapse dolines, i.e. steep-sided sinkholes of elliptical or circular chape, are characterized by the abrupt and fast failure in the overburden of the cave. The caves are most often within in the gypsum caprock, but may in other cases be in the overlying sediments if an upward migrating pipe has developed (e.g. Waltham et al., 2005; Warren, 2006). Both, dissolution sinkholes and collapse dolines are not strictly related to gypsum karst but may also be controlled by rock salt dissolution. Sinkholes and dolines from gypsum often show diameters of few tens of meters (Waltham et al., 2005), while those associated with salt dissolution may be larger with diameters up to $100 m$ or more, see e.g. the Äbtissinengrube sinkhole in the Kyffhäuser mountains (North Thüringen, Germany, 160m x 200m, developed during three days in the 16th century), the Meade 1879 collapse, Kansas, or the Wink Sink, Nord Texas (both described in Waltham et al., 2005). Submarine circular sinkhole structures have partly reached even larger dimensions up to $2 \mathrm{~km}$ (e.g. McDonnell et al., 2007; Bertoni and Cartwright, 2005).

In the region of Gross Flottbek in Hamburg circular sinkholes and local ground motion shocks have been observed for several hundred years and interpreted as indicators of gypsum karst. Although surface-related subsidence features are relatively well documented, the extent and depth of a possible gypsum karst as well as its possible hazard for the city of Hamburg has never been investigated and quantified.

Morphological and geophysical studies in Hamburg indicate two types of sinkholes in close proximity (Fig.2 and Buurman, 2010): (1) slow and continuously subsiding zones with diffuse border structures (here declared as dissolution sinkholes) and abrupt and episodic collapsing pipes (dropout sinkholes) that are limited by sub-vertical faults and 
are possibly related to ground shaking during a partial failure event (compare with microearthquake observations at the Guatemala City, February 2005, sinkhole with a diameter of $20 \mathrm{~m}$ and a depth of $100 \mathrm{~m}$ ). Both types are also observed in other areas of gypsum karst (Benito et al., 1995; Waltham et al., 2005). The largest sinkholes in Hamburg have a diameter of $100 \mathrm{~m}$ or more (e.g. Bahrenfeld lake, $118 \mathrm{~m}$ ), and depth probing of specific sinkholes indicate a depth of the dissolution centers or void space of $185 \mathrm{~m}$ or more (Othmarscher Dorfteich, see Grube, 1973).

Most of the sinkholes in Hamburg have developed under slow continuous subsidence. Average rates have been estimated in between 2-5 mm/yr (Paluska, 2002, see also results of PSInSAR deformation measurements). Active sinkholes may influence existing or new buildings and infrastructure. For instance, Grube (1973) mentions the usage of stabilizing techniques for high buildings close to existing sinkholes. Vice versa, the human activity may influence the stability of the salt-gypsum-water system. Such a feedback has been recognized in urban areas elsewhere (e.g. Benito et al., 1995; Waltham et al., 2005; Johnson, 2008; Soriano and Simon, 1995, 2002). The sinkhole hazard may increase by mass-loading of critical areas (Waltham et al., 2005), by pumping of ground water (Waltham et al., 2005), or when drilling into underground cavities and aquifer systems under overpressure. A good example is the 2005 sinkhole generation in the gypsum mine Moncalvo in Piemont, Italy.

In some areas in Flottbek the occurrence of ground shaking (Fig.2), often at the same location, indicates that paleo-caves or dissolution fronts exists. However, so far larger caves or karst systems have not been evidenced. Some borehole lithological profiles SE of the epicentral area indicate high porosity between 90 and $140 \mathrm{~m}$ depth (red-filled circles in Fig.2). Within one borehole a $10 \mathrm{~m}$ long void space has been indicated between $54 \mathrm{~m}$ and $64 m$ depth (borehole Othmarschener Dorfteich, Grube, 1973).

We analyze the April 2009 ground shocks in Gross-Flottbek and investigate possible sources as cave collapse or shear rupture. Specific questions concern the depth, the strength, and the source mechanism of the events, the possible existence of paleo karst systems or dissolution fronts, the role of gypsum or salt as well as the evaluation of the possible ground shaking hazard. 


\section{Seismological study}

\subsection{Waveform characterization and observations}

\subsubsection{The 8 April 2009 event}

The strongest shock of the sequence occurred on 8/9 April some minutes after midnight (local time). It was felt only locally in a small area of about $\pm 100 \mathrm{~m}$ (Fig.2). Partly, habitants left their houses because of the unusual shock and the fear of more ground shaking. Luckily, the event has been recorded by three local seismic stations, DES2 and DES4 at DESY (Deutsches Elektron Synchrotron) in an epicentral distance between 900 $m$ and $1200 m$, and station HAM3 at the Geophysical Institute, University of Hamburg, in about $6.8 \mathrm{~km}$ distance (Fig.3). DES2 is equipped with a Guralp CMG-3TD (360 s, GPS synchronized) and DES4 with a Guralp CMG-6TD system (60 s). DES2 is 20m below surface. DES4 was unfortunately not time synchronized, but the time shift and drift could be estimated by cross-correlating body-wave phases from teleseismic earthquakes on both close-by stations at DESY (Appendix B, Fig. B.1). HAM3 is equipped with an STS2 (100s) and a Quanterra datalogger. The maximal ground displacement at the closest station DES2 was about 0.03 millimeter at a period of $0.6 \mathrm{~s}$. The maximal ground velocity measured at DES2 was $0.35 \mathrm{~mm} / \mathrm{s}$ and the maximal acceleration $8 \mathrm{~mm} / \mathrm{s}^{2}$. Ground acceleration directly at the epicenter has not been measured. The corresponding values at HAM3 were $0.001 \mathrm{~mm}$ at $0.9 \mathrm{~s}, 0.012 \mathrm{~mm} / \mathrm{s}$ and $0.2 \mathrm{~mm} / \mathrm{s}^{2}$, respectively.

The seismograms in Fig.3 are dominated by surface waves with emerging onsets and velocity dispersion. The amplitudes of the surface waves attenuate quickly with distance from the epicenter so that the signals in $6.8 \mathrm{~km}$ distance are only slightly above the noise level. However, identification of Rayleigh and Love waves on rotated horizontal components could be used to estimate a backazimuth at the three stations, which confirmed the correct association of the epicenter at the area of felt reports (Fig.2). The smallest slowness of the surface wave-train at about $1 \mathrm{~Hz}$ is about $2.2 \mathrm{~s} / \mathrm{km}$ indicating a group velocity of about $450 \mathrm{~m} / \mathrm{s}$. Surface waves at higher frequencies propagated slower with $\approx 230 \mathrm{~m} / \mathrm{s}$ or even less. The penetration depth of these types of waves is small, in the range between roughly 20 to $150 \mathrm{~m}$ (1/3 wavelength rule of thumb). Both, the fast amplitude attenuation and the absence of faster, deeper reaching surface waves is a clear seismological indication that the event occurred in the uppermost sediment layers beneath the quarter of Flottbek Markt, i.e. above $200 \mathrm{~m}$ depth. Similar to other events close to the surface, a man-made cause of the ground shaking, e.g. from an explosion, may be questioned. However, the occurrence time after midnight, the occurrence of aftershocks as well as the presence of Love waves give strong arguments for a natural 
origin of the shocks.

\subsubsection{Aftershocks}

We developed and applied a simple search algorithm for the two closest stations, DES2 and DES4, in order to detect possible fore- or aftershocks from the same source region. The waveforms of the 8 April event and the 21 April aftershock were cut out and used as master waveforms in a cross-correlation application over the continuous time traces. Common peaks in the correlograms of the two stations, above an empirically defined threshold were demanded for the final association of a detection. Between 7 April and 18 May 2009 one possible fore- and about 20 possible aftershock were detected. However, most of the detections were weak and in the range of the noise amplitudes and only a single detection (8 April 22:58) was jointly found with both master waveforms.

On 22 April the University of Hamburg installed three seismic stations in close proximity to the epicentral area, two of which functioned well (open triangles in Fig.2). A large amount of traffic- and man-induced weak noise burst could be identified (Fig. 5), but no clear aftershock or earthquake activity. Finally, the evaluation of all available traces and detections by eye led to the conclusion that only two aftershock events were unambiguous (see Fig.4). The first aftershock occurred only $1 \mathrm{~h}$ after the main shock on 8 April 2009, 22:58 UTC, and had a moment about 50 times smaller than the main shock. The second aftershock occurred on 21 April 2009, 18:04 UTC, after nearly 2 weeks and was half the size of the main shock on 8 April. The waveforms of the three events are similar, but not exactly identical (Fig.4). Time differences between individual peaks vary only slightly indicating that the foci of the aftershocks must have been close to the focus of the main shock (range of about $50 \mathrm{~m}$ or smaller if a quarter wavelength rule is considered).

\subsubsection{Sedimental velocity model and phase identification}

Fig. 6 shows the velocity and density model we derived for the region of Flottbek Markt (see Kühn et al., 2010). Most important for our interpretation are velocities within the uppermost $500 \mathrm{~m}$ and the depth of the sediment-salt transition.

The P-wave velocity at the surface is $1500 \mathrm{~m} / \mathrm{s}$ and increases gradually to a value of $2690 \mathrm{~m} / \mathrm{s}$ at a depth of $150 \mathrm{~m}$. The near-surface velocities are constrained from hammer blow refraction experiments at different sites above the OLD diapir (Kühn et al., 2010). Additionally, critical porosity models suggest that water-saturated, unconsolidated sediments close to the free surface are better characterized by a suspension in water with a $\mathrm{P}$-wave velocity at the water point, i.e. $1500 \mathrm{~m} / \mathrm{s}$, and a very high $v_{P} / v_{S}$ ratio (Mavko et al., 2003). Between 150 and $170 \mathrm{~m}$ we have a transition to velocities of $4500 \mathrm{~m} / \mathrm{s}$ 
that are typical for halite. The depth of the top of the OLD is locally constrained from 3D gravity inversion (e.g. Dahm et al., 2010), H/V ambient vibration studies and from surface-wave velocity dispersion as measured from small-scale seismic arrays (Kühn et al., 2010). The sediment-salt transition is assumed to occur over a zone of about $20 \mathrm{~m}$ thickness. A smooth transition zone is viewed as an average model along the path from the epicenter to stations DES2 and DES3, because the OLD has some topography (see discussion below). Station HAM3 is outside the OLD and the sediment-salt transition is possibly not appropriate for the path to HAM3.

The S-wave velocity is set at the surface to $210 \mathrm{~m} / \mathrm{s}$ and increases to $1000 \mathrm{~m} / \mathrm{s}$ at a depth of $150 \mathrm{~m}$. It is mainly constrained from the results of Rayleigh wave inversion from nearby seismological array measurements (e.g. Kühn et al., 2010, and Fig.2 for location of arrays). Within the halite we assume S-wave velocities at about $2100 \mathrm{~m} / \mathrm{s}$.

Fig.7 shows three component seismograms at DES2 and DES4 rotated to the great circle radial, transversal and vertical (up) direction. The seismograms are dominated by surface waves of relatively low frequencies. The seismograms have not been lowpass filtered (except the anti-aliasing filter at about $50 \mathrm{~Hz}$ ), and the dominance of low frequencies is unusual for an earthquake of this small strength and such short distances. Because the travelpath to the stations is short, the intrinsic damping is insignificant for all of the high frequency waves at about $5 \mathrm{~Hz}$. We postulate that the dominance of low frequencies is not due to attenuated high frequency waves but controlled by a relatively long rupture duration of possibly 0.3 seconds or even larger.

Love waves are observed on the transversal component with similar amplitudes compared to the Rayleigh waves on the vertical and radial component. Love waves at HAM3 have slightly larger amplitudes than Rayleigh waves. This is noteworthy, because a vertical single force or vertical linear force-dipole, force systems typical for cavity collapses, do not excite Love and SH waves.

The body waves in Fig.7 are emergent and weak and the dominance of surface wave amplitudes already indicates a shallow source within the uppermost $150 \mathrm{~m}$. We plotted the theoretical arrival times of the diving/refracted P- and S-waves for a source in $80 \mathrm{~m}$ depth and compare them with observed picks. The S-wave arrivals are in general weak and are difficult to be unambiguously identified. However, the general good accordance to body wave onsets confirms the choice of the velocity model and the correct choice of the epicentral distance. A shallow source is in accord with observations, but a precise depth estimate from body wave arrivals is not possible with only three seismograms. 


\subsection{Source depth and mechanism estimated from waveform modeling}

Looking at the continuous time traces between 25 April and 10 May, one can recognize a large number of small events of impulsive origin. These events occur preferably on working days, during working hours. For example, on 28 April, about 147 such events can be identified between 4:30 and 14:50 UTC (Fig. 5). Over some periods they occur almost regularly every 3 minutes, a group of two to five events within about 40 seconds. Amongst each other, the seismograms of these events show a very similar waveform pattern, but their relative strength varies. The strongest were visible on the whole network, but with a low signal-to-noise ratio. The origin of the impulsive events was from a pile driver at a construction work at DESY in a depth of about $30 \mathrm{~m}$. The working area was documented at $9.8775 \mathrm{E}$ and $53.5792 \mathrm{~N}$ and is consistent with the arrival of waves at the four close-by stations.

We use these artificial signals and synthetic waveform modeling for a direct comparison with the micro-earthquake data to estimate the depth of the event. It was possible to improve the signal to noise ratio (SNR) of the artificial shocks by means of stacking. The timings required to stack the traces were determined by cross-correlation in a 2pass process: In the first pass, one of the stronger 28 April shocks was used as master waveform. In the second pass, the master waveform was replaced with a preliminary stacked trace built from the timings determined in the first pass. The timings of the peaks in the cross-correlation were taken from the vertical component of DES4, which had the highest signal-to-noise ratio, but the stacking was applied to all available time traces at DES4, DES2 and the other two close-by stations. Altogether 147 shocks have been stacked and the SNR improved by a factor of 12 .

The source depth and the shallow S-wave velocity structure both control the velocity dispersion and the amplitude pattern of surface waves. We know the sedimental S-wave velocity model within the uppermost $200 \mathrm{~m}$ quite well from independent measurements at sites nearby. Therefore, a modeling of surface waves provides constraints to the source depth problem, as well as to limit the range of possible source mechanisms and rupture duration. We evaluate the source depth by calculating synthetic depth sections and comparing them with observed ground displacement. Since epicentral distances are partly within few wavelength from the source, the near field terms are included in the waveform modeling, which we performed with a reflectivity program (Wang, 1999, version qseis5.7). Fig. 8 gives an overview for station DES2, which recorded both, the artificial shocks of shallow origin and the micro-earthquake, in a similar distance (701 and $919 \mathrm{~m}$, respectively). A vertical linear dipole has been used as excitation, which has an azimuthindependent radiation pattern for vertical and radial traces. Clear differences can be 
recognized in synthetic seismograms associated with different depths. For shallow point sources, the waveforms contain higher frequencies and more prominent single phases, while deeper sources generate a stronger low-frequency ringing at the end of the coda of the waves. The synthetic seismograms at $701 \mathrm{~m}$ associated with a $30 \mathrm{~m}$ deep source fit well the observations of the pile driver source. In contrary, the micro-earthquake data are better explained by a point source between 60 and $120 \mathrm{~m}$ depth. A similar conclusions was found when analyzing data at DES4. The waveform modeling therefore suggests that the event occurred in about $90 \pm 30 \mathrm{~m}$.

In order to better evaluate the source problem we run a systematic grid search inversion on depth, moment and moment tensor. We varied only $M_{x z}, M_{y z}$ and $M_{z z}$. This corresponds to a systematic search of two source types, a pure dip slip shear dislocation on a vertical plane and a vertical linear vector dipole associated with a possible collapse. Full waveform amplitude spectra have been fitted at all stations and three components. For HAM3, only the vertical and transversal components were chosen, but weighted by a factor 5 in order to balance the relatively higher attenuation at a distance of $7 \mathrm{~km}$ compared to the near epicentral stations DES2 and DES4. Although the traces at HAM3 are relatively noisy, they contribute to the source mechanism problem since clear Love waves are observed at HAM3. The results confirm a clear misfit minimum (L2 norm, ground displacement residuals) at a source depth of $100 \mathrm{~m}$ (Fig. 9), similar to the visual inspection and modeling of traces. Additionally, the moment, rise time and the source mechanism was estimated at $M_{0} \approx 8.9 \cdot 10^{9} \mathrm{Nm}, T_{r} \approx 0.3 \mathrm{~s}$ (Fig. 9), and $M_{y z}=6.4 \cdot 10^{9} \mathrm{Nm}, M_{z z}=-9.28 \cdot 10^{9} \mathrm{Nm}, M_{x z}=-2 \cdot 10^{9} \mathrm{Nm}$, respectively. The source mechanism corresponds to a point source with $16 \%$ isotropic component (implosive, e.g. from a vertical linear force-dipole). The remaining deviatoric tensor can be explained by a dip slip normal faulting shear crack with a strike of $17^{\circ}$, a dip of $73^{\circ}$ and a rake of $-90^{\circ}$. The large shear faulting component justifies to denote the Flottbek events "micro-earthquakes", although the possible cause is different from that of a normal tectonic earthquake.

Fig. 10 compares all three components time traces, vertical, radial and transversal, at the three available stations with synthetic seismograms of the best source at a depth of $100 \mathrm{~m}$. Although only amplitude spectra were used for inversion, a reasonable fit to all three component seismograms is observed. The source time function of $0.3 \mathrm{~s}$, indicated from the inversion, is in accord with the time data. Note that the strong Love waves on the transversal component seismograms (tra) can only be explained by inventing a shear dislocation source component. The moment magnitude of the "best source" is in the range of $M_{W} 0.6$ (Fig. 9). However, both, the shape and strength of the moment tensor and the depth of the source are not well resolved and should be taken as a possible but not as a unique solution. 
Fig. 11 compares theoretical and observed peak ground acceleration. Theoretical values have been calculated with the parameters of the best point source at a focal depth of $100 m$ using a full waveform reflectivity approach, and using the sedimental velocity model of Fig. 6. Maximal peak-to-peak acceleration was extracted from a dense grid of synthetic seismograms between 0.2 and $7 \mathrm{~Hz}$. The measured acceleration at the seismic stations DES2 and DES4 were 8.4 and $6.5 \mathrm{~mm} / \mathrm{s}^{2}$, respectively (Fig. 6). Perceptibility reports from local inhabitants (34 reports received) have been collected by the University of Hamburg, and associated with three categories, strongly felt (intensity up to IV), occasionally felt and not felt (intensity below II). We assume that an intensity of IV can be associated with a ground motion of about $40-300 \mathrm{~mm} / \mathrm{s}^{2}$ at $3 \mathrm{~Hz}$ dominant frequency (e.g. Aktison and Kaka, 2007).

Fig. 11 shows that the epicentral location, shape and magnitude-decay of perceptibility is well explained by the predicted ground acceleration and our source model. The modeling further confirms that damage could not be expected from the main shock, because epicentral ground acceleration was most likely everywhere below $150 \mathrm{~mm} / \mathrm{s}^{2}$. The ground motion modeling and perceptibility reports could not be used to further constrain the source depth, because the uncertainties of the reports are too large. However, it is interesting that a shallow source at $30 \mathrm{~m}$ depth produced a too strong decay of intensities at the two seismic stations, while a deep source at $180 \mathrm{~m}$ depth predicted a slightly larger region of perceptibility.

\section{Discussion}

The Flottbek April 2009 superficial ground shocks are very likely related to sedimental paleo-cave collapses or salt dissolution, and pose a rare example of recording such events by seismometers (e.g. Neunhöfer, 1997; Wust-Bloch and Joswig, 2006; Land, 2009). The Flottbek events are recorded by three seismometers only, and the resolution of retrieved source parameters is therefore limited. On the other hand, additional information as the reports of residents, previous work on the structure of the OLD, historical reports of local ground motion shocks and the available geodetic information in the epicentral area help to unravel the origin of the unusual events.

The main shock on 8 April 2009, 22:06:25 (UTC), had a moment of about $8.9 \cdot 10^{9} \mathrm{Nm}$ and an equivalent moment magnitude of about $M_{W}$ 0.6. Without doubt two aftershocks with moment magnitude $M_{W}-0.6$ and $M_{W} 0.33$ occurred on 8 April, 22:58, and 21 April, 18:04, respectively. Even weaker aftershocks are indicated by automatic waveform-based triggers but are difficult to verify against noise. The seismological recordings indicate a source depth at about $100 \pm 20 \mathrm{~m}$. Since the micro-earthquakes are so shallow above 
$120 \mathrm{~m}$ depth and the region is densely populated the epicenters are best determined by perceptibility reports (Fig. 11) at 9.873700 E and 53.569676 N $( \pm 150 \mathrm{~m})$, in accord with body and surface wave arrivals at the seismic stations. As expected for an "earthquake" of this weakness, and from the modeled epicentral ground acceleration below $50 \mathrm{~mm} / \mathrm{s}^{2}$ no damage to buildings was reported. No surface features such as depressions, tilt or cracks were observed. This indicates that the event did not origin in the top few $m$ below the ground surface. In Fig. 11 the effect of focal mechanism upon the distribution of ground acceleration is shown.

The observed Love waves require that shear faulting components were present during rupture. The waveform modeling indicate a normal faulting component with a strike of about $17^{\circ}$. Additionally, a vertical subsidence movement is indicated from the radiation pattern, represented by a vertical linear vector dipole and possibly associated with a collapse at depth. The rupture duration was $0.3 s$ or possibly larger, which is unusually long for an earthquake of this weakness. Given the moment of the main shock, the shear wave velocity and density of sediments in $100 \mathrm{~m}$ depth $\left(v_{S} \approx 570 \mathrm{~m} / \mathrm{s}, \rho \approx 1930 \mathrm{~kg} / \mathrm{m}^{3}\right.$, see Fig.6), scaling relations of earthquakes assuming a stress drop between $1 M P a$ and $10 \mathrm{MPa}$ predict a fault length and average slip in the range of about $26 \mathrm{~m}$ and $4 \mathrm{~cm}$, and of $12 \mathrm{~m}$ and $19 \mathrm{~cm}$, respectively. Assuming a rupture velocity $v_{r}$ of only $50 \%$ of the shear wave velocity, the expected rupture duration is $0.09 s$ and $0.04 s$, respectively, which is smaller than the observed rupture duration of $T_{r}=0.3 \mathrm{~s}$. Vice versa, if $v_{r}$ and $T_{r}$ are hold fixed, the predicted fault length would be nearly $100 \mathrm{~m}$. Either the stress drop was much smaller than $1 \mathrm{MPa}$ in order to explain an unusual long fault (and smaller slip), or the rupture velocity of the process was smaller than $285 \mathrm{~m} / \mathrm{s}$, i.e. smaller than $0.5 v_{S}$. Collapse earthquakes associated with vadose caves in sediments rupture possibly slower than pure tectonic earthquakes (see e.g. Krüger and Klinge, 2002), even if shear rupture components are involved, and we therefore assume that the long rupture duration was not necessary related to a large fault dimension.

The possible collapse of cavities in karst may be compared to rock-fall events in mines. The 11 September $1996 M_{L} 4.8, M_{W} 4.53$ Potash mine collapse in Teutschenthal, Germany, is used for comparison. The mine was out of production for two years before the collapse event, and no direct man-made actions are protocolled immediately before the event (Krüger and Klinge, 2002). Excavating chambers had a typical height of $5 \mathrm{~m}$, and the estimated source radius was $920 \mathrm{~m}$, assuming a circular rupture plane with a total area of $2.7 \mathrm{~km}^{2}$. The collapse occurred in a depth of $700 \mathrm{~m}$, and after the event a surface subsidence of about $45 \mathrm{~cm}$ was measured (Krüger and Klinge, 2002). The rock fall event excited strong well developed Rayleigh wave trains, but also some energetic Love waves (Krüger and Klinge, 2002). This appears similar to the Flottbek events. Exceptional was also the long and complex rupture process, which could be divided into three sub- 
events occurring over a period of $1.5 \mathrm{~s}$ and associated with a non-continuous eastward propagation of the rupture, and a strong compressional wave onset with its maximum after $2.5 \mathrm{~s}$ after the first onset. This energetic late arrival has been associated with the arrival of the hanging wall block on the galleries floor (Krüger and Klinge, 2002). The complex waveforms of body waves and the relatively long duration of the rupture and collapse process looks similar to the Flottbek events, but is on a different scale since the Teutschenthal collapse was much stronger than the Flottbek events.

Earthquakes triggered or induced by gas recovery and reservoir depletion may be taken as another example for rupturing shallow faults in sediments. Two cases from the North European basin have been studied in detail: the 7 May $2001 M_{W} 4.1$ Ekofisk North Sea earthquake in a depth of about $2 \mathrm{~km}$ (e.g. Ottenmöller et al., 2005) and the 20 October $2004 M_{W} 4.4$ Rotenburg. N-Germany, earthquake in a depth of about $6 \mathrm{~km}$ and with a rupture length of about $4.5 \mathrm{~km}$ and a source duration of about $1.3 \mathrm{~s}$ (e.g. Dahm et al., 2007; Cesca et al., 2010). In both cases the rupture duration was unusual long in comparison to crustal earthquakes, and strong surface waves were generated. Thus, a slow rupture velocity and long rupture duration, and the excitation of energetic surface waves, cannot distinguish a possible collapse from a possible shear rupture event.

The estimated source depth of the Flottbek event at $100 \mathrm{~m}$ is about $50 \mathrm{~m}$ above the top of the salt diapir, and it is unknown whether gypsum caprock is present there. At least, local gravity (e.g. Dahm et al., 2010) and ambient vibration H/V measurement (e.g. Kühn et al., 2010) did not indicate thick gypsum caprock beneath the epicenter, like in regions further SE and W. Unfortunately, the question cannot be definitely resolved beneath Gross Flottbek because borehole-based deep stratigraphic profiles are absent there.

The epicentral region (Fig.12) is characterized by a relatively strong topographic slope of nearly semi-circular shape ( $\approx 10 \mathrm{~m}$ step from 35 to $25 \mathrm{~m}$ a.s.l.), striking at the epicenter in approximately SW-NE direction (Fig.12). The water drainage system is towards S and feeding the small non-seasonal Flottbek stream, that flows in the Elbe river in a distance of about $2 \mathrm{~km}$ from the epicenter. The salt diapir beneath the epicenter is at a depth of about $170 \mathrm{~m}$. The western border of the OLD is situated approximately beneath the epicenter, and further to the west the diapir is strongly dipping towards west (Fig.12 and Dahm et al., 2010). The epicentral area is further characterized by slow continuous relative subsidence. PSInSar data (Schäffer, pers. commun.) indicate a $800-1000 \mathrm{~m}$ large bowl of ongoing relative subsidence with an average rate of about $0.7 \mathrm{~mm} / \mathrm{yr}$ (see PSInSar data in Fig.12, and further description in Dahm et al., 2010). Some buildings in the epicentral area have cracks in their walls, which have been considered related to slow sinkhole-driven deformation. (Reuther et al., 2007; Buurman, 2010, and KrausJohnsen, pers. commun.). At least two geological sinkhole structures are known in the 
epicentral area. One, the Flottbek Markt sinkhole, is characterized by inclined border faults indicating continuous slow subsidence (e.g. Buurman, 2010). It is associated with a buried suffosion sinkhole, e.g. a subsidence process where the soil cover is flushed into stable rock fissures. The other significant structure, the nowadays filled-up Wobbe See about $250 \mathrm{~m}$ northwest to the Flottbek Markt sinkhole and directly bordering the event epicenters, has nearly vertical ring faults indicating a collapse-like style of subsidence. According to the geological, stratigraphical and ground penetrating radar studies of Buurman (2010), it is associated with a dropout sinkhole, i.e. an upward void migration and progressive roof failure within cohesive soil.

Historical reports of the last 250 years list about 25 percepted ground shocks in the epicentral area of the April 2009 events (Table 1 and Fig.2), possibly occurring at the same location close to the Wobbe See sinkhole. Some of them appear to have caused minor damage (Table 1). The last one occurred on 8 April 2000 and was most likely stronger than the April 2009 events (seismic recordings are unfortunately not existing). Other even stronger events occurred on 29 September 1929, 19 March 1960, and 30 January 1963.

Any source model of the April 2009 events must explain the different observations and compiled information. We exclude shallow motion on deep-seated tectonic faults as a cause of the events. The hypocenters are located above the salt diapir, which would decouple shear stress from the deeper crust. There are also no geological, seismological or geodetic indications for such a fault. Thus, the cause of the repeated ground shaking events must be a local phenomena. The collapse of moor lenses (e.g. suggestions in Koch, 1918) at a depth of $100 \mathrm{~m}$ is not very likely in our opinion, because they can be assumed weak structures that would possibly compact aseismically. They would also hardly explain the repeated occurrence of events at a single spot, and are therefore also excluded as the earthquake generating mechanism.

We discuss three possible models (Fig. 13): (I) the collapse of paleo caves in gypsum karst, (IIa) the shear-rupture on shallow sedimental splay faults related to a dissolution front of a suffosion sinkhole, and (IIb) the upward migration and failure of (ephemeral) soil cavities (regolith arches) in cohesive sediments above the salt. Model I is associated with processes in paleo-karst, while II is regarded as active salt karst. A suffosion sinkhole is formed by the continuous down-washing of soil into fissures in salt rock (e.g. Waltham et al., 2005).

Gypsum (paleo-) karst may exist at the envisaged depth level and is known to generate rock fall and collapse events (e.g. Parise and Trocino, 2005; Benito et al., 1995). The salt diapir in Bad Segeberg about $60 \mathrm{~km}$ north of Hamburg poses a good example of paleo gypsum karst. The gypsum caves developed in the caprock of the salt diapir and are nowadays dry at a depth of about 15 to $25 \mathrm{~m}$ below surface and can be inspected 
over a length of several $100 \mathrm{~m}$. Single halls and galleries span several tens of meters. Collapse earthquakes or subsidence sinkholes, however, are to our knowledge not known in Bad Segeberg. Although thick caprock and gypsum layers are observed at other positions over the OLD in Hamburg, the existence of a paleo-karst system beneath Gross Flottbek remains speculative. Borehole data are missing and $\mathrm{H} / \mathrm{V}$ ambient vibration and gravity data have not indicated anomalies at $100 \mathrm{~m}$ depth or thick gypsum layers beneath Flottbek Markt.

The radiation pattern of seismic waves and the source mechanism can likely be explained by the collapse of a paleo cave. For instance, the collapse of the Teutschenthal rockfall event induced Love and Rayleigh waves in a similar relative strength as in our case. They can be associated with the shear failure on subvertical normal faults in the ceiling layers of a collapsing cave. Such a failure model along roof faults is supported by structural and laboratory studies (McDonnell et al., 2007; Loucks et al., 2004). It has also been suggested by Neunhöfer (1967) in a study on salt-dissolution induced seismicity in Thüringen, Germany. The paleo-karst in gypsum model would possibly constrain the largest expected ground shaking events, since these are related to the volume and width of the chambers in a mechanical weak gypsum rock, which are according to Waltham et al. (2005) typically smaller than $25 \mathrm{~m}$.

The dashed line in Fig 13 indicates the shear horizon of an idealized suffosion-controlled subsidence cone in unconsolidated sand and soil, with its center at about the Flottbek Markt sinkhole. If the flushing center of the Flottbek Markt sinkhole is situated in 100 $m$ depth within a possible gypsum karst, the slope of the subsidence cone is $\approx 11^{\circ}$ only, (Fig. 13), and is thus much smaller than the typical effective friction angle of fine-grained, unconsolidated soils at about $20^{\circ}$. Thus, the large area of active subsidence related to the soil suffosion beneath the Flottbek Markt sinkhole may possibly suggest a deeper flushing center than $100 \mathrm{~m}$, indicating that thick gypsum karst above the salt top in about $170 \mathrm{~m}$ is not controlling the processes or even not existing.

Another argument against the paleo karst model concerns its difficulties to explain the repeated triggering of co-seismic events only in the Flottbek Markt and Wobbe See area in Gross Flottbek.

Model (IIa) and (IIb) both assume deep-seated dissolution in $>170 \mathrm{~m}$ depth of either gypsum or salt. The dissolution front may be thought of as a specific point or as a slowly migrating front, where sealing layers have been disrupted and enable flow of water. Brine and water may migrate down-slope the diapir border towards W-NW, similar to what is indicated for the Gorleben salt diapir (e.g. Klinge et al., 2002). Groundwater salt concentration measured in boreholes at a depth of $500 \mathrm{~m}$ W-NW of Flottbek are larger than $3000 \mathrm{mg} / \mathrm{l}$ (see Fig. 13 in Dahm et al., 2010), indicating down-slope flow of brine. 
Rock salt dissolution can be fast and may cause significant subrosion. For instance, the Ochtmisser Kirchsteg sinkhole at the Lüneburg salt diapir, about $60 \mathrm{~km}$ south of Hamburg, shows subsidence rates of about $21.4 \mathrm{~cm} / y r$ (Schäfers and Trapp, 2007). Neunhöfer (1997) reports subsidence rates up to $100 \mathrm{~cm} / \mathrm{yr}$ in sinkholes above Zechstein salt in Helfta, Thüringen, Germany. In these cases, the subsidence rates have most likely been enhanced by ground water lowering in nearby mines (Neunhöfer, pers. commun.). Borehole-based relative subsidence measurements at different depths indicates increasing subsidence rates with depth and subsidence down to the depth of the uppermost rock salt layers, lying beneath a gypsum caprock (Schäfers and Trapp, 2007). Micro-earthquakes, however, have so far not been observed at the Lüneburg Ochtmisser Kirchsteg sinkhole. The existence of a suffosion-type sinkhole as indicated in Flottbek Markt and the observed bowl-shaped subsidence-rate at the surface can be better explained by a deepseated flushing point for soil, which would lead to a slightly larger dipping angle of about $20^{\circ}$ (Fig. 13).

The ground shaking events in model II nucleate within a cohesive soil above the salt bedrock (Fig. 13). In model IIa we assume that shear occurs on a cohesive patch on the slumping plane of the suffosion cone. The phenomena may be compared to a creeping landslide in steep montain valleys, except that the slide in our case is below surface. Walter and Joswig $(2008,2009)$ used small-scale seismological arrays to monitor weak earthquakes associated with the gliding of such an instable slide. Repeated microearthquakes are typically observed occurring at single spots where friction is increased, e.g. at bending points of the sliding plane, or at points where large blocks of bedrock cut the slide. Applied to Hamburg the model predicts a frictional anomaly in the soil column beneath the epicenter. Model IIa bears a smaller hazard since no abrupt surface collapse is predicted and micro-earthquakes would not migrate upward and can be expected of comparable strength and comparable occurrence rate, as long as the suffosion is in a steady state. A problem, however, may concern the cumulative slip of subsequent micro-earthquakes over the last 100 years (Table 1). The measured subsidence rate at the surface indicates an inter-seismic shear loading on a steeply dipping plane of only slightly more than $0.7 \mathrm{~mm} / \mathrm{yr}$, which cannot explain $>40 \mathrm{~mm}$ slip with a recurrence rate of about 10 years.

Model IIb assumes that roof-failure of an upward migrating soil cavity is occasionally causing ground shaking events. Soil-cavities are created if the lower sand is suffosed into fissures in the gypsum or salt over a longer period of months, years or tens of years. The soil cavities may be relatively stable when they are small and at depth, so that compression arches may develop within the clay above them. Most soil cavities propagate vertically upwards and the grows and upward migration may accelerate with time. Ultimately, dropout sinkholes at the surface can form within days or weeks and are 
recognized as a major geo-hazard in karst in general (Waltham et al., 2005). According to Buurman (2010) the Wobbe See sinkhole structure was possibly formed by such a process.

Historic reports of upward migrating soil cavities above salt exist, as for instance the Mead 1879, Kansas (USA), collapse event (e.g. Waltham et al., 2005), the Wink Sink, North Texas (USA) (e.g. Waltham et al., 2005), or the Loco Hills sinkhole in New Mexico (USA, e.g. Land, 2009). Toulemont (1985) analyses a soil cavity over gypsum beneath Paris with a concealed void of $2500 \mathrm{~m}^{3}$ (may be compared to a sphere with a diameter of $17 \mathrm{~m}$ ), that had been found in 1975 beneath railway engineering works. The development of the 1981 Winter Park sinkhole in Florida is discussed by Waltham et al. (2005) as representative for large dropout sinkholes. Failure started with the sudden disappearance of a large tree, with a swishing noise, and then soil was progressively lost in the newly formed hole over the next two days. After achieving its stability, the sinkhole partially filled with water. The description has some similarities to a tree-falling event occurring in a stormy winter night 1834 in Hamburg (Altonaer Mercurius, 31. January 1834, critically reviewed by Koch, 1918).

Breccia pipes with sub-vertical circular border faults, partly of impressive dimensions, are observed in many geological records and verify that upward piping is a standard deformation style accompanying salt dissolution (e.g. Eliasen and Talbot, 2005; Epstein, 2001; Bertoni and Cartwright, 2005; McDonnell et al., 2007; Loucks et al., 2004).

Salt dissolution induced seismicity was monitored and studied over many years in East Germany, often in relation to mining activites. Neunhöfer (1997) reports several cases where seismicity preceeded sinkhole collapse above salt / gypsum, and was used to predict such collapse events (e.g. for the Karl Liebknecht Hütte in Eisleben: if seismicity exceeded a critical level, the working area was evacuated). The magnitudes of these dissolution-induced seismicity reach up to $M_{L} 1.5$ for a Buntsandstein caprock layer of maximal $200 \mathrm{~m}$ thickness (Neunhöfer, 1997). Two huge sinkholes with more than $\approx 100 \mathrm{~m}$ diameter have been observed during the flooding of a salt mine in Bernburg/Stassfurt in the former East Germanny, from the mid 1970ties to mid 1980ties (7/8 Nov 1969 and 17 Feb 1975). The accompaning seismicity was measured and used to better control the flooding and sinkhole formation (Neunhöfer, pers. commun.). Land (2009) and Rick Aster (pers. commun.) reports another case of seismic precursors six hours before an anthopogenic sinkhole collapse (final diameter of $111 \mathrm{~m}$ and $\approx 64 \mathrm{~m}$ depth) in Eddy Co., New Mexico. Malovichko et al. (2009) describes the sinkhole formation above the potash mine Berezniki 1 in Russia in 2009, which has been preceeded and accompanied by micro-earthquakes. Micro-earthquake seismicity and weak low frequency events were also recorded prior to a controlled formation of a collapse sinkhole in Lorraine, France, on 13 February 2009 (Phillipe Jousset, pers. communication). In other cases, 
however, seismicity has rarely been observed during soil migration. The migration of a soil cavity from a depth of $170 m$ to the surface may be slow if the soil has some cohesive strength, and weak ground shaking events may represent indicators for such a migration process. However, except for the fact that the perceptibility radius of historical shocks at Gross Flottbek apparently decreased in a systematic manner from 1928 until 2009, we have no knowledge or indication that the ground shaking events in Hamburg migrate upward. The progressive roof failure of a soil cavity is most often related to variations in pore water pressure within the soil. Critical are conditions where pore water pressure is greater within the soil than it is immediately adjacent to the cavity wall (e.g. Tharp, 1999, 2003). This may be created when the drainage of the cavity during water table decline is faster than the falling pore water pressure in the soil, or when, after a drought, a new wetting front of rain-fed percolation water advances though a dry soil. The triggering multiple sinkhole events during rainfall and thunderstorms has often been observed (see Florida and Georgia sinkholes discussed in Waltham et al., 2005). Similarly, soil cavity failure may be artificially triggered, for instance by re-directed drainage input, pumped water table decline or by vibrations from artificial sources. (see references in Waltham et al., 2005).

Model IIb integrates most of the given observations in Flottbek, but we cannot exclude the models I and IIa without further investigations.

\section{Conclusion}

Between 8 and 21 April 2009 three weak ground shaking events were recorded by three local seismic stations in the city area of Hamburg. The first event was the strongest and had a magnitude of $M_{W} \approx 0.6$ (moment of $M_{0} \approx 8.9 \cdot 10^{9} \mathrm{Nm}$ ). The two aftershocks were 2 respectively 50 times smaller. Waveform similarities indicate that all three events occurred a few meters from each other. The shallow hypocenters are indicated from the seismograms which are dominated by Rayleigh and Love waves. The measured maximal acceleration was $8 \mathrm{~mm} / \mathrm{s}^{2}$ in $970 \mathrm{~m}$ and only $0.2 \mathrm{~mm} / \mathrm{s}^{2}$ in $6800 \mathrm{~m}$ epicentral distance. Our waveform modeling estimates a maximal acceleration in the epicenter below 50 $\mathrm{mm} / \mathrm{s}^{2}$.

The two strongest events were felt by local population within an area of about $250 \mathrm{~m}$ radius. No damage was reported in questionnaires collected by the University of Hamburg, and no surface effects such as steps, holes or ground fissures had been recognized. Geodetic measurements indicate ongoing relative subsidence of a circular area around the epicenters with $\approx 250 \mathrm{~m}$ radius with a rate of about $0.7 \mathrm{~mm} / \mathrm{yr}$. The events occurred in the densely populated area of Gross Flottbek close to the old market (Flottbek Markt) 
and a former lake (Wobbe See), both associated with sinkhole structures caused by salt dissolution or gypsum karst (Niedermayer, 1962; Grube, 1974; Reuther et al., 2007; Buurman, 2010). The epicenters location is at the southern border of the partly filled-up cropout Wobbe See sinkhole, nearly at the same position where about 25 of similar sized or slightly larger ground shaking events occurred within the past 250 years, as indicated in historical reports (Table 1).

The modeling of ground displacement indicates that the event centroids were at a depth between 60 to $120 \mathrm{~m}$, and therefore above the top of the OLD diapir at about $170 \mathrm{~m}$ depth. The occurrence of strong Love waves indicates that shear rupture on a subvertical, about $17^{\circ}$ striking fault was involved in the failure process. Additionally, a vertical single or linear dipole force, as expected for collapse events, is indicated with a comparable strength. Noteworthy is the relatively long duration of the source process of about $0.3 s$ or more.

We discussed three possible models to explain repeated occurrence of small ground shaking events in a single spot: (I) the collapse of paleo caves in gypsum karst, (IIa) the shear-rupture on shallow sedimental splay faults related to a dissolution front of a suffosion sinkhole, and (IIb) the upward migration and roof failure of a soil cavity in cohesive sediments above the salt. The three models bear quit different hazard for ground motion and instant soil failure.

Model IIb explains best all our observations and compiled data, although we cannot exclude the other two models completely without further studies. It is likely that similar ground shaking events will occur in future at the same or a close-by position, and the ultimate scenario would be the sudden formation or re-activation of a dropout sinkhole at the surface.

\section{Acknowledgments}

We thank Families Bahr, Vossberg and Wiemers for their help. Daniela Kühn and Matthias Ohrnberger helped with the velocity model. Frank Krüger read and improved the manuscript. The study has benefited from results and work obtained during the HADU project (03G0621A), which was funded by BMBF within the GEOTECHNOLOGIES program. Three reviewers provided very helpful comments to improve the clarity of the manuscript and our English. 


\section{References}

Aktison, G. and Kaka, S., 2007. Relationship between felt intensity and intrumental ground motion in the Central United States and California. Bull. Seism. Soc. Am., 97:497-510.

Baldschuh, R., Fritsch, U., and Kockel, F., 2001. The basement block pattern in Northwest Germany. In Baldschuh, R., Binot, F., Fleig, S., and Kockel, F., editors, Geotektonischer Atlas von Nordwest-Deutschland und dem deutschen Nordsee-Sektor, pp. cartographic map, 1:500000. Schweitzerbart.

Benito, G., del Campo, P., and Gutierrez-Elorza, 1995. Natural and human-induced sinkholes in gypsum terrain and associated environmental problems in NE Spain. Environmental Geology, 25:156-164.

Bertoni, C. and Cartwright, J., 2005. 3D seismic analysis of circular evaporite dissolution structures, Eastern Mediterranean. Journal Geological Society, London, 162:909-926.

Buurman, N., 2010. Zirkular-Strukturen in der Metropolregion Hamburg und ihre potenziellen Geogefahren. PhD thesis, Geologisch-Pal. Institut, University of Hamburg.

Cesca, S., Heimann, S., Stammler, K., and Dahm, T., 2010. Automated procedure for point and kinematic source inversion at regional distances. J. Geophys. Res., 115 B06304:doi:10.1029/2009JB006450.

Dahm, T., Krüger, F., Stammler, K., Klinge, K., Kind, R., Wylegalla, K., and Grasso, J., 2007. The $m_{w}=4.4$ Rotenburg, Northern Germany, earthquake and its possible relationship with gas recovery. Bull. Seism. Soc. Am., 97(10.1785/0120050149):691704 .

Dahm, T., Kühn, D., Ohrnberger, M., Kröger, J., Wiederhold, H., Reuther, C., Dehghani, A., and Scherbaum, F., 2010. Combining geophysical data sets to study the dynamics of shallow evaporites in urban environments: application to Hamburg, Germany. Geophys. J. Int., 181(10.1111/j.365-246X.2010.04521.x):154-172.

Eliasen, A. and Talbot, M., 2005. Solution-collapse breccias of the Minkinfjellet and Wordiekammen Formations, Central Spitsbergen, Svalbard: a large gypsum palaeokarst system. Sedimentology, 52:775-794.

Epstein, J., 2001. Hydrology, hazard and geomorphical development of gypsum karst in the Northern Black Hills, South Dakota and Wyoming. In U.S. Geological Survey Karst Interest Group Proceedings, Water-Resources Investigations Report 01-4011, pp. 30-37. 
Grube, F., 1970. Baugeologie der Lockergesteine im weiten Hamburger Raum. In Mitt. Nr. 69, Geologisches Landesamt Hamburg, pp. 109-160. Grundbau Taschenbuch Wilhelm Ernst \& Sohn, Berlin.

Grube, F., 1973. Ingenieurgeologische Erkundung der Erdfälle im Bereich des Salzstocks Othmarschen-Langenfelde (Hamburg). Report, Geol. Landesamt Hamburg.

Grube, F., 1974. Experiences of engineering geology on the top of the saltdome Othmarschen-Langenfelde (Hamburg). In Engineering Geology, Volume T47, B1-B7. Eng. Geol. Hannover-Essen, Geol. Symp. Int. Assoc.

Hamm, F., 1956. Naturkundliche Chronik Nordwestdeutschlands. Landbuch Verlag, Hannover.

Heimann, S., 2010. A robust method to estimate kinematic earthquake source parameter. PhD thesis, University of Hamburg, MIN Faculty, submitted in December 2010, 151, pp.

Johnson, K., 2008. Gypsum-karst problems in constructing dams in the USA. Environ. Geol., 53:945-950, doi10.1007/s00245-007-0720-z.

Klinge, H., Köthe, A., Ludwig, R.-R., and Zwirner, R., 2002. Geologie und Hydrogeologie des Deckgebirges über dem Salzstock Gorleben. Z. Angew. Geol., 2:7-15.

Koch, E., 1918. Der Bahrenfelder See. In Beiheft zum Jahrbuch der Hamburgischen Wissenschaftlichen Anstalten XXXV 1917, pp. 1-44. Mitteilungen aus dem MineralogischGeologischen Institut in Hamburg, Otto Miessners Verlag, Hamburg.

Koch, E., 1938. Aufbau des tieferen Untergrundes im weiteren Umkreis der geplanten Elbhochbrücke mit einer Karte 1:25000. In unveröff. Gutachten vom 10.0\%.1938, Archiv GLA. Geologisches Landesamt Hamburg.

Krüger, F. and Klinge, K., 2002. The 1996 Teutschenthal Potash Mine Collapse: an unusual event with an unusual mechanism. In Korn, M., editor, Ten years of German Regional Seismic Network (GRSN), pp. 206-210. Senate Commission for Geoscience.

Kühn, D., Dahm, T., Ohrnberger, M., and Vollmer, D., 2010. Imaging a shallow salt diapir using ambient seismic vibrations beneath the densely built-up city area of Hamburg, Northern Germany. J. of Seismology, pp. revised

Land, L., 2009. Anthopogenic sinkholes in the Delaware basin region: West Texas and Southeastern New Mexico. WTGS Bulletin, 48(6):10-22.

Leydecker, G., 1986. Erdbebenkatalog für die Bundesrepublik Deutschland mit Randgebieten f"ur die Jahre 1000-1981. Geol. Jb, E36. 
Leydecker, G., 1998. Earthquake catalogue for the Federal Republic of Germany and Adjacent Areas for the Years 800 - 2004. Federal Institute for Geoscience and Natural Resources, Stilleweg 2, D-30566 Hannover, Germany, pp. 35-37.

Loucks, R., Mescher, P., and McMechan, G., 2004. Three-dimensional architecture of a collapsed-paleocave system in the Lower Ordovician Ellenburger Group, central Texas. AAPG Bulletin, 88:545-564.

Malovichko, D., Dyagilev, R., Shulakov, D. Y., and Butyrin, P., 2009. Seismic monitoring of large-scale karst processes in a potash mine. In Tang, C., editor, Controlling seismic hazard and sustainable development of deep mines, V.2, pp. 989-1002. Rinton Press, New York.

Mavko, G., Mukerji, T., and Dvorkin, J., 2003. The rock physics handbook: tools for analysis in porous media. 325, pp.

McDonnell, A., Loucks, R., and Dooley, T., 2007. Quantifying the origin and geometry of circular sag structures in northen Fort Worth Basin, Texas: Paleocave collapse, pull-apart fault systems, or hydrothermal alteration ? AAPG Bulletin, 91:1295-1318.

Neunhöfer, H., 1967. Statistische Gesetzmäßigkeiten der zeitlichen Verteilung sowie des Energie-Häufigkeits-Zusammenhanges von Gebirgsschlägen und die Möglichkeiten einer statistischen Gebirgsschlagsprognose. Akademi Verlag Berlin, Veröffentlichungen des Instituts für Geodynamik Jena, 11:1-79.

Neunhöfer, H., 1997. Überwachung nichttektonischer Erderschütterungen in Mittel/Ostdeutschland mit lokalen seismischen Stationen. In Neunhöfer, H., Börngen, M., Junge, A., and Schweitzer, J., editors, Zur Geschichte der Geophysik in Deutschland, pp. 201-206. Jubiläumsschrift, Deutsche Geophysikalische Gesellschaft 1922 - 1997.

Niedermayer, J., 1962. Die geologischen Verhältnisse im Bereich des Salzstocks von Hamburg-Langenfelde. Mitteilung Geol. Landesamt Hamburg, 39:167-175.

Ottenmöller, L., Nielsen, H., Atakan, K., Braunmiller, J., and Havskov, J., 2005. The 7 May 2001 induced seismic event in the Ekofisk oil field, North Sea. J. Geophys. Res., B10301:i10.1029/2004JB003374.

Paluska, A., 2002. Geologische Stellungnahme zum Bebauungs-Planentwurf Gross Flottbek 10 (Osdorfer Marktplatz) . Report, Geol. Landesamt Hamburg, pp. 1-1.

Parise, M. and Trocino, A., 2005. Gypsum carst in the Crotone Province (Calabrioa, Southern Italy). Acta Carsologica, pp. 370-382. 
Reinhold, K., Krull, P., and Kockel, F., 2008. Salzstrukturen Norddeutschlands: geologische Karte 1:50000. Bundesanstalt für Geowissenschaften und Rohstoffe Hannover.

Reuther, C., Buurman, N., Kühn, D., Ohrnberger, M., Dahm, T., and Scherbaum, F., 2007. Erkundung des unterirdischen Raums der Metropolregion Hamburg - Das Projekt HADU (Hamburg - A Dynamic Underground). Geotechnik, 30:11-20.

Schäfers, P. and Trapp, T., 2007. Gutachten Bericht Nr. 3 - Kurzfassung: Senkungsstruktur Ochtmisser Kirchsteig in Lüneburg. Report, CDM Consult GmBH, D-44793 Bochum, Stadt Lüneburg, Project No 57053.

Schmidt, C., 1963. Erdbeben in Hamburg-Groß-Flottbek im Januar 1963. report, Baubehörde Hamburg.

Sieberg, A., 1932. Erdbebengeographie. In Gutenberg, B., editor, Handbuch der Geophysik IV, pp. 688 - 1005. Bornträger, Berlin.

Sieberg, A., 1940. Beiträge zum Erdbebenkatalog Deutschlands und angrenzender Gebiete für die Jahre 58 bis 1799. Reichsverlagsamt Berlin, pp. 1-195.

Soriano, M. and Simon, J., 1995. Alluvial dolines in the Central Ebro basin, Spain: a spatial and developmental hazard analysis. Geomorphology, 11:295-309.

Soriano, M. and Simon, J., 2002. Subsidence rates and urban damages in alluvial dolines of Central Ebro basin (NE Spain). Environmental Geology, 42:467-484.

Tharp, T., 1999. Mechanism of upward propagation of cover-collpase sinkholes. Engineering Geology, 53:23-33.

Tharp, T., 2003. Cover-collapse sinkhole formation and soil plasticity. Am. Soc. Civil Engineers Geotechnical Special Publication, 122:110-123.

Toulemont, M., 1985. Les risques d'instabilite lies au karst gypseux lutetien de la region parisienne. Bulletin liason Laboratoires Ponts et Chaussees, 150/151:109-116.

Walter, M. and Joswig, M., 2008. Seismic monitoring of fracture processes from a creeping landslide in the Vorarlberg Alps. First Break, 26:131-135.

Walter, M. and Joswig, M., 2009. Seismic characterisation od slope dynamics by softrocklandslides: The super-Sauze case study. In Malet, J.-P., R. A. B. T. E., editor, Proceedings of the International Conference on Landslide Processes: from geomorphologic mapping to dynamic modelling, pp. 215-220. CERG Editions,Strasbourg.

Waltham, T., Bell, F., and Culshaw, M., 2005. Sinkholes and subsidence. Springer. 
Wang, R., 1999. A simple orthonormalizing method for stable and efficient computations of Green functions. Bull. Seism. Soc. Am., 89:733-741.

Warren, 2006. Evaporites - Sediments, Resources and Hydrocarbons. Springer, AA Dordrecht, 1035, pp.

Wust-Bloch, G. and Joswig, M., 2006. Pre-collapse identification of sinkholes in unconsolidated media at dead sea area by "nanoseismic monitoring" (graphical jackknife location of weak sources by few, low-snr records). Geophys. J. Int., 167(10.1111/j.1365264X.2006.03083.x):1220-1232. 


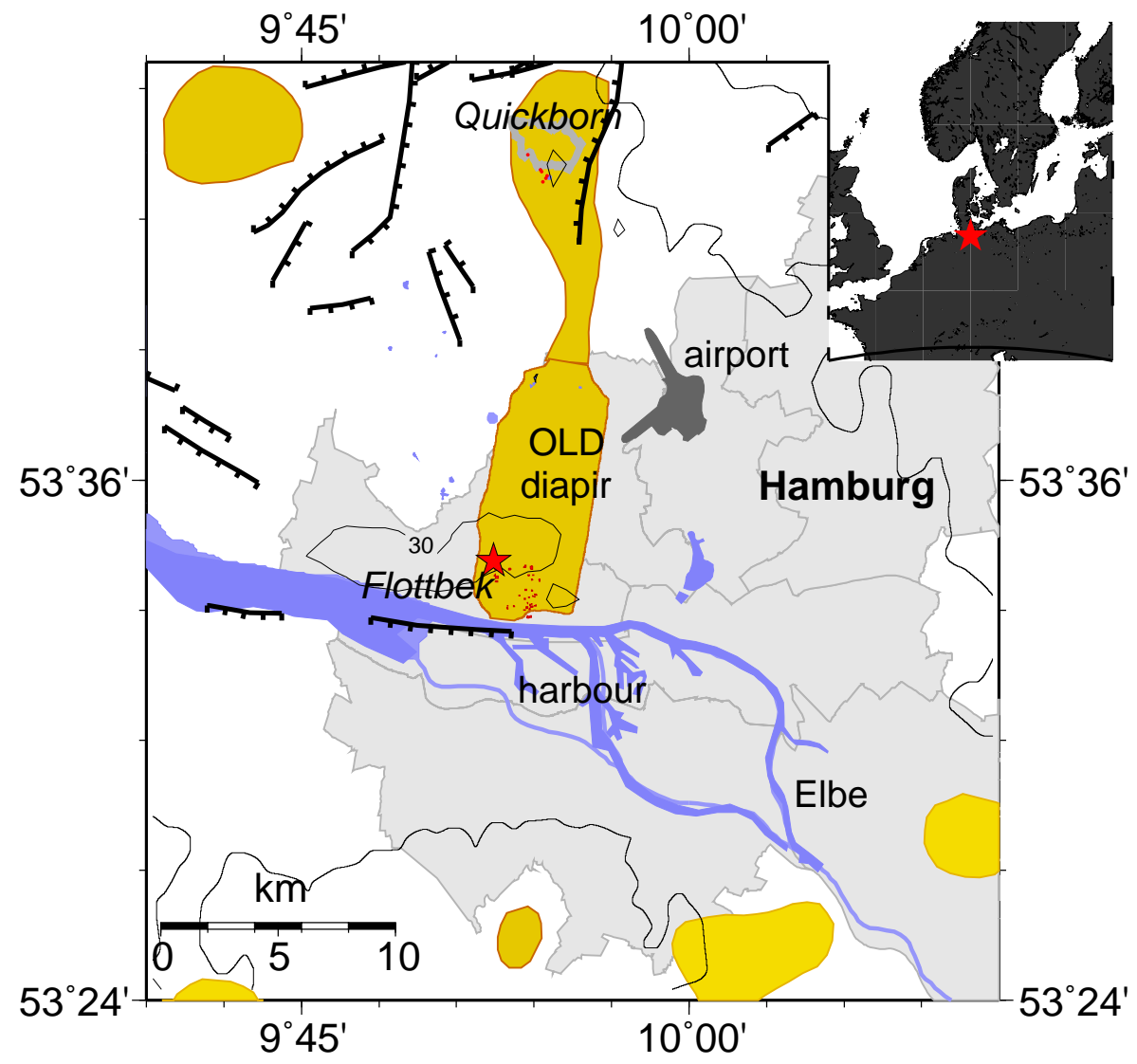

Figure 1: Overview to salt diapirs and pillow in the Hamburg region (see Reinhold et al., 2008). The dashed lines outline the Othmarschen-Langenfeld salt diapir (OLD) after Grube (1973) and Dahm et al. (2010). Red-filled star indicates the epicenter of the April 2009 ground shaking events and small polygons on the OLD indicate sinkholes features. The Tertiary Zechstein (salt) faults are based on reflection seismic profiles and are taken from Baldschuh et al. (2001). The contour line indicates $30 \mathrm{~m}$ elevation. 


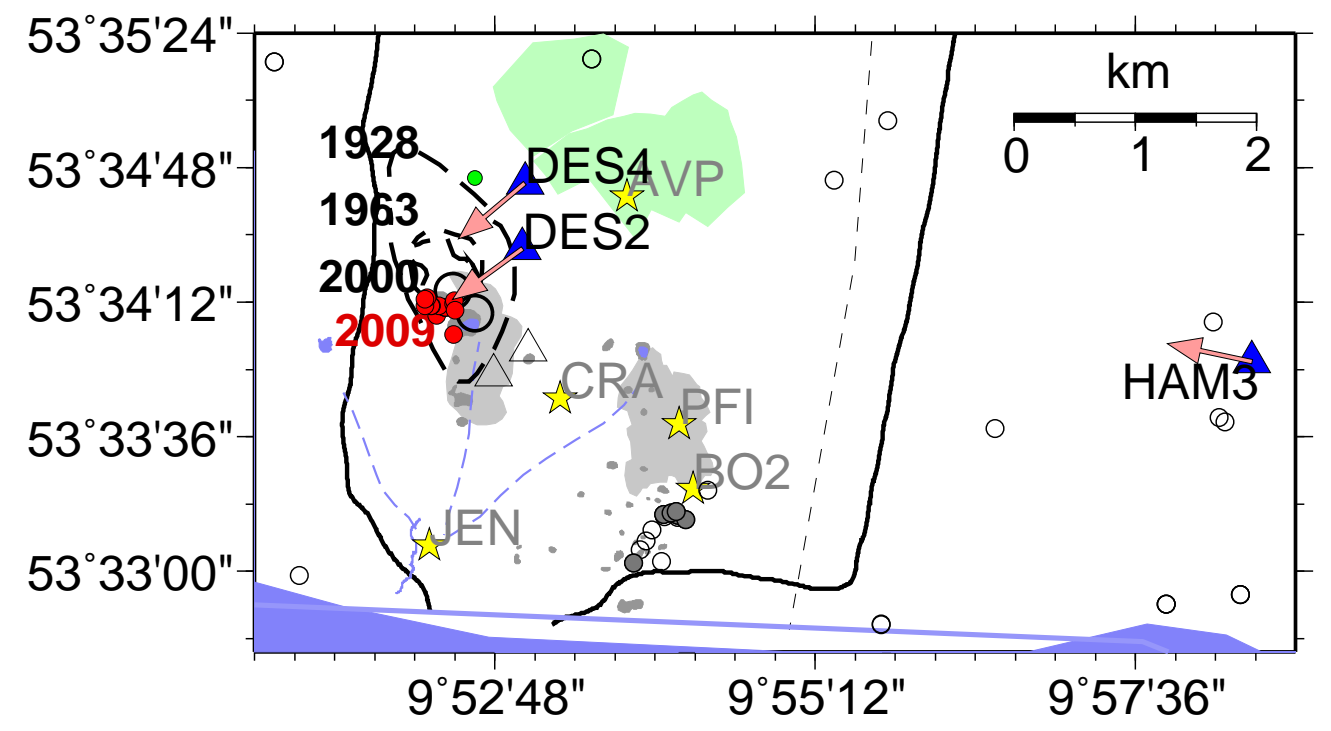

Figure 2: Sinkholes (dark-gray filled polygone, from Koch, 1918; Niedermayer, 1962; Grube, 1970, 1973, 1974; Paluska, 2002; Buurman, 2010) and subsidence areas (grea filled, see Niedermayer, 1962; Buurman, 2010) in the southern region of the OLD. Red filled circles represent positions where we received felt reports of the April 2009 shocks (epicentral area). Dashed lines show felt areas of three stronger historic shocks in 1928, 1963 and 2000 (z.B. Paluska, 2002, , R. Taugs, pers. commun.). The large open circles show estimated epicenters from about 25 other shocks between 1760 and 2000 (see appendix), and the green filled circle indicates the epicenter of an artificial pile-driver source that is compared in the analysis. Permanent seismic stations are declared by blue filled triangles (DES2, DES4 und HAM3), and open triangles declare temporal stations. Arrows mark directions towards the April 2009 shocks as estimated from surface wave polarization. The open circles declare available borehole locations, filled circles those boreholes where open pore space at depth is indicated. 


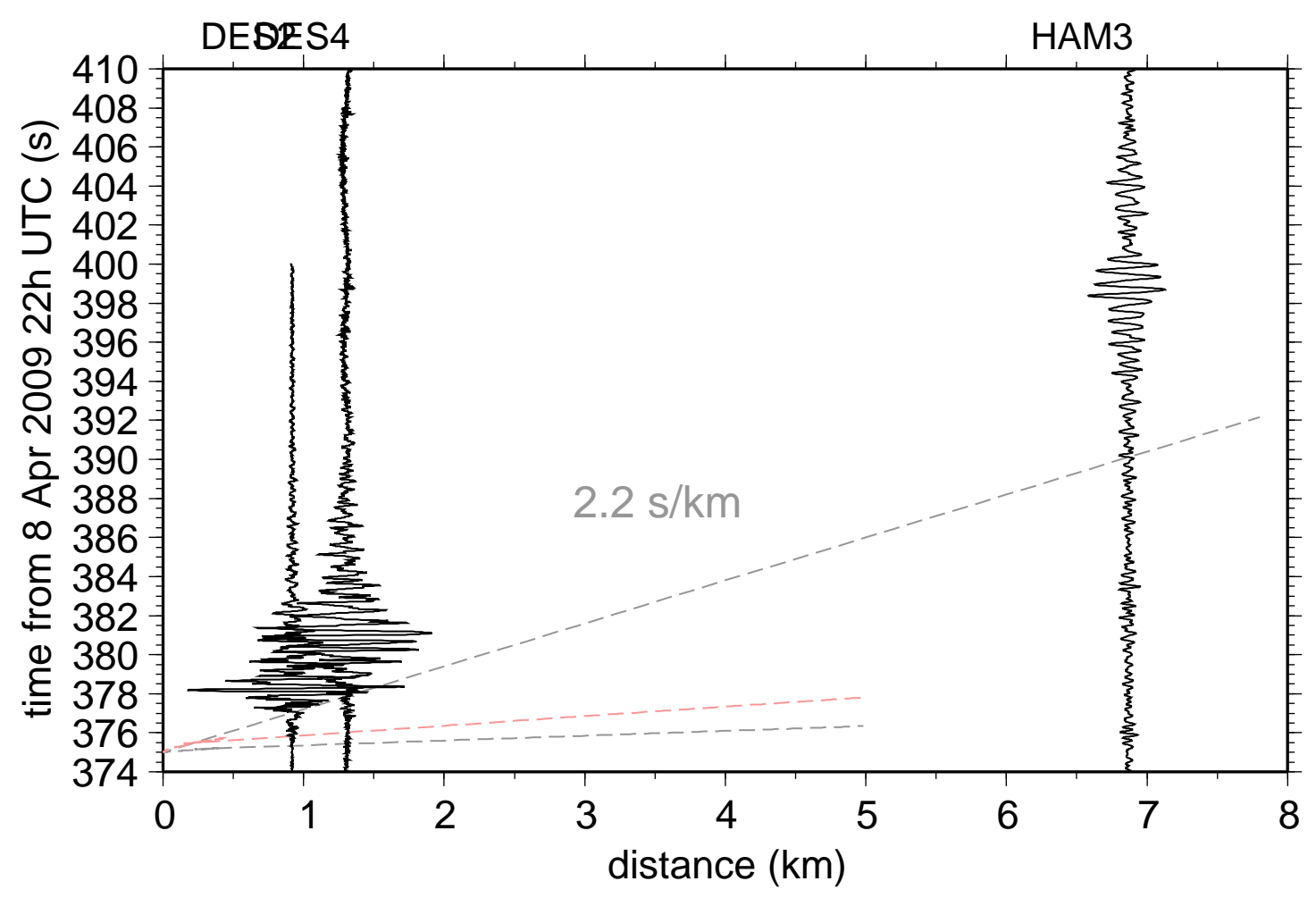

Figure 3: Time-distance recordsection of seismograms from 8 April 2009. For DES2 and DES4 the raw data (vertical component) are plotted with a common scale. For HAM3 (north component) data had been bandpass filtered (0.5-3 Hz) and amplified by a factor of 100. The event origin time is at 375.1 s (22:06:25.1 UTC, 9 April 2009 0:6:25.1 local time) and the epicenter has been taken at the center where ground shaking was reported. 


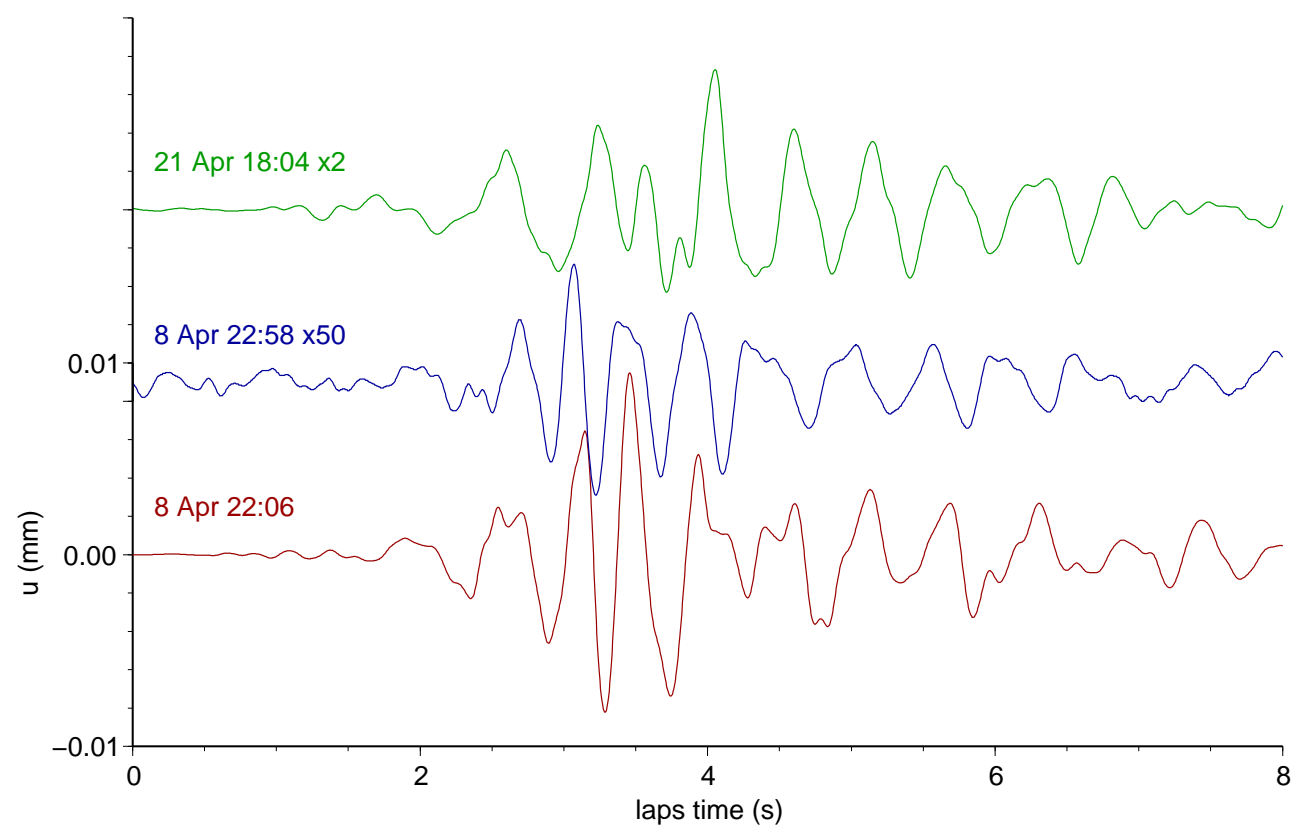

Figure 4: Comparison of waveforms of the main and the two strongest aftershocks at station DES2 (vertical component, displacement, filtered between 0.5 and $10 \mathrm{~Hz}$ ). The displacement range is defined for the main shock on 8 April 22:06. The displacement amplitudes of the aftershocks are amplified by a factor 2 and 50 . 


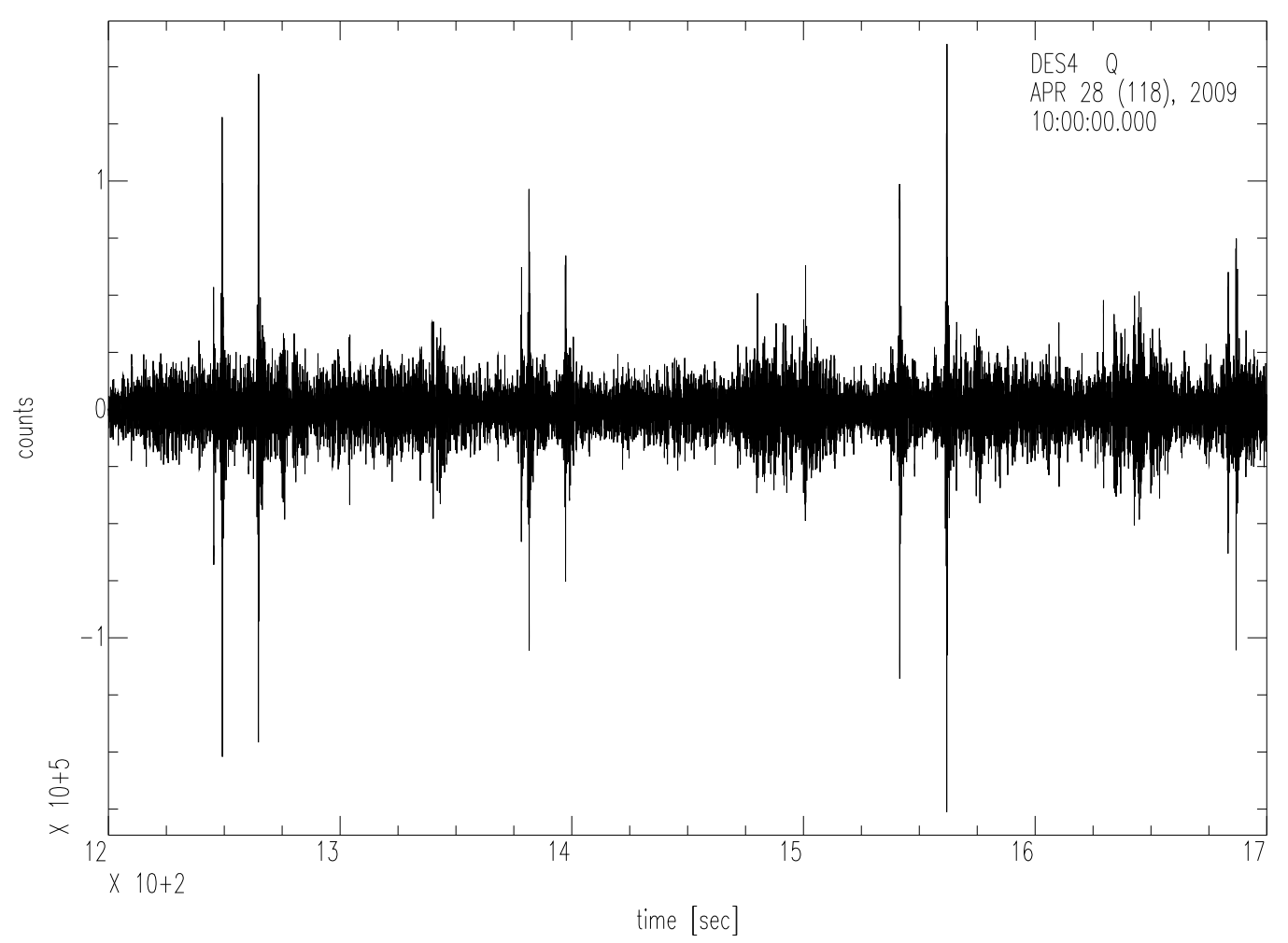

Figure 5: Noise record at DES4 (VER) on 28 April 2009 10:20 - 10:28 UTC. Regular shocks occurred on 28 April from $6: 30 \mathrm{~h}$ to $16 \mathrm{~h}$ (local time) and can be associated with construction work at DESY in $417 m$ distance, where a pile driver was used to destroy erratic blocks of rocks in the underground (max. $40 \mathrm{~m}$ depth). The regular shocks are later used for a comparative study. 

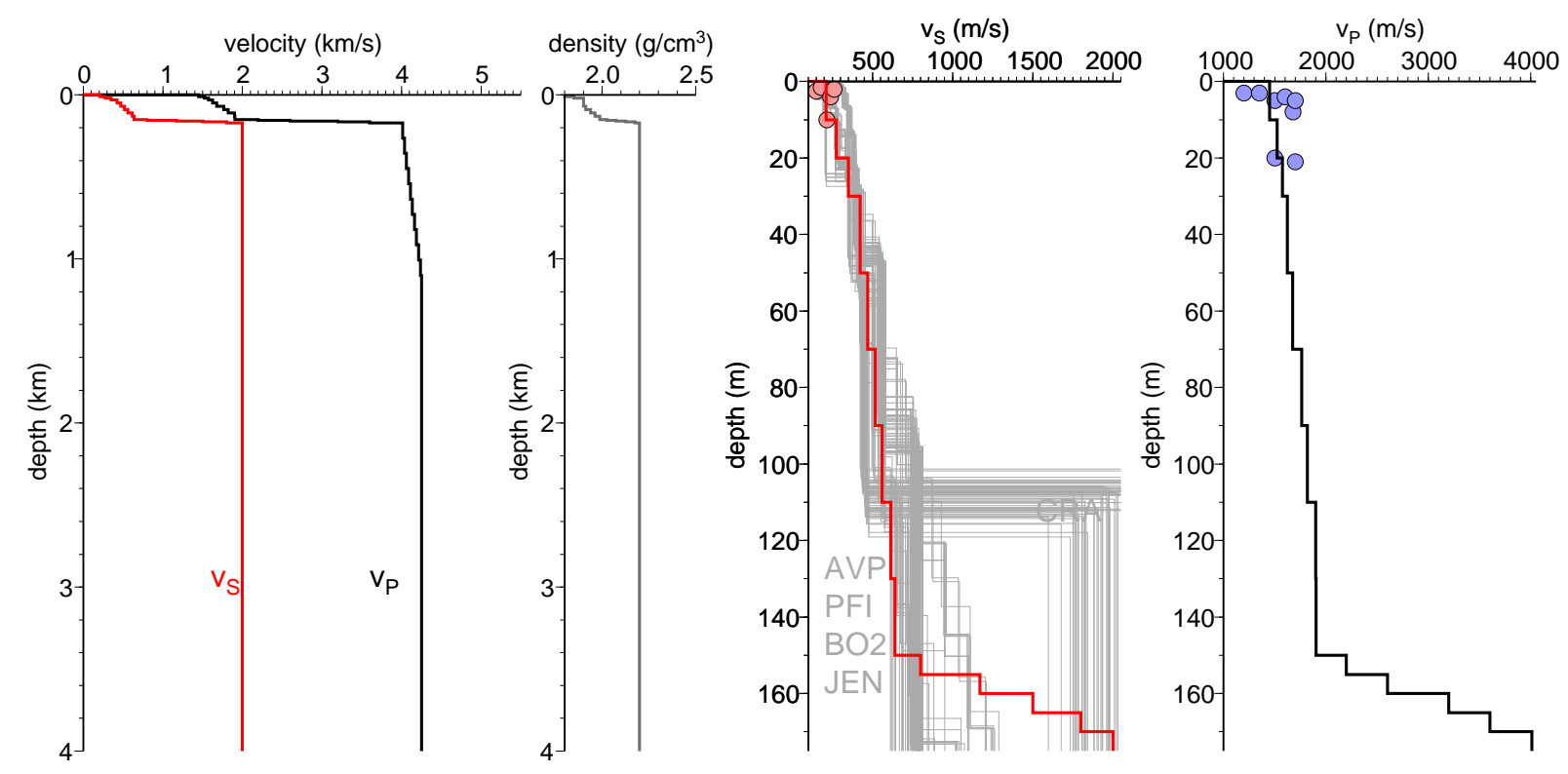

Figure 6: Left: The solid red and black lines give the average velocity and density models that have been used for the full waveform modeling. Right: Velocity model for the uppermost $170 \mathrm{~m}$. Filled circles indicate velocities as estimated from small scale hammer blow refraction experiments at different sites above the OLD diapir. Grey models are best solution $v_{S}$ models from the inversion of Raleigh wave dispersion curves and H/V spectral peaks (e.g. Kühn et al., 2010). (see Fig.2 for location of arrays). 


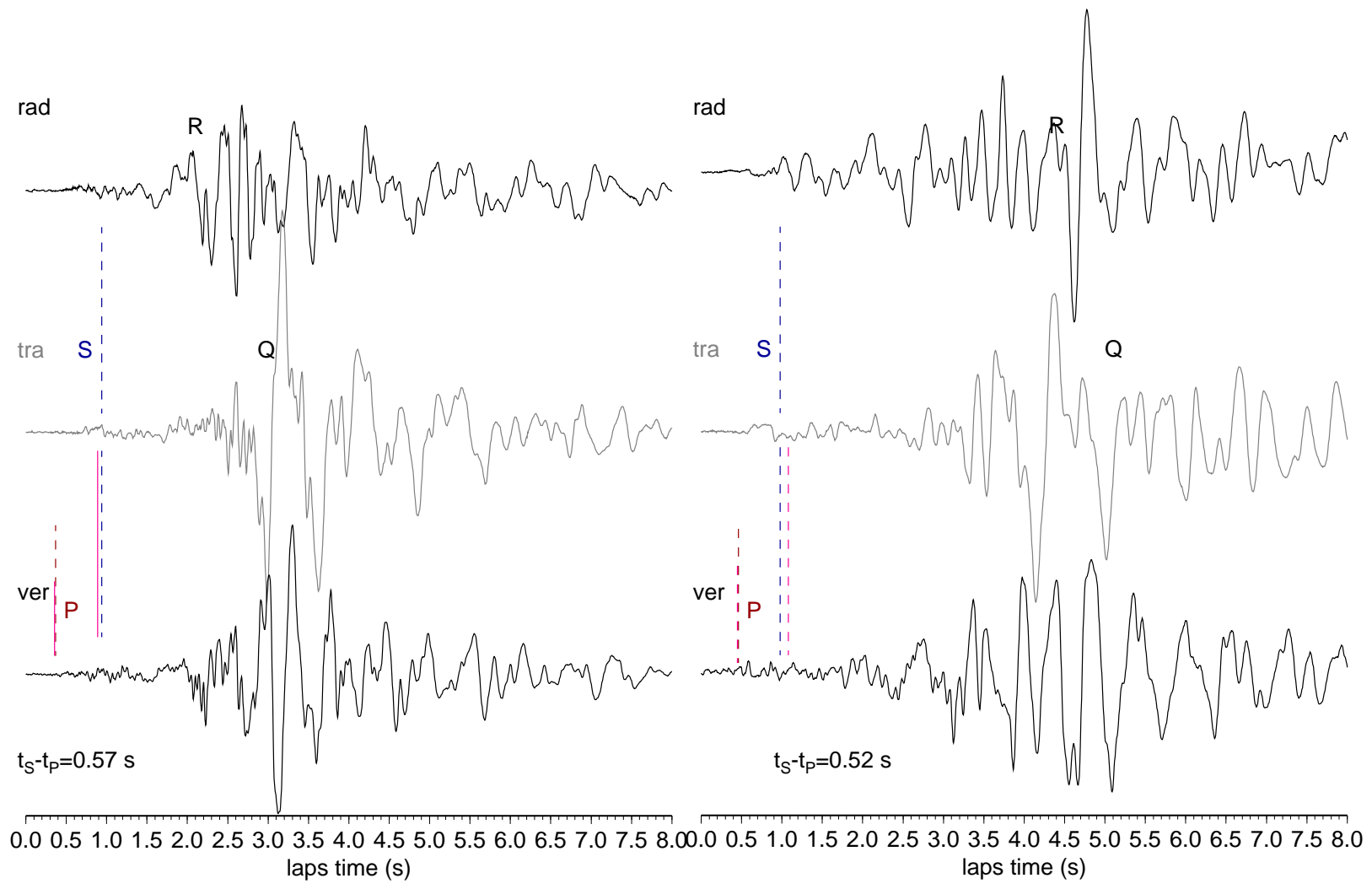

Figure 7: Three component seismograms (velocity proportional, rad, tra and ver) at station DES2 (left) and DES4 (right) are shown with a common scale for the 8 April 22:06 main shock. Dashed lines declare picked and theoretical arrival times of $\mathrm{P}$ and $\mathrm{S}$ waves and a source depth of $80 \mathrm{~m}$. 


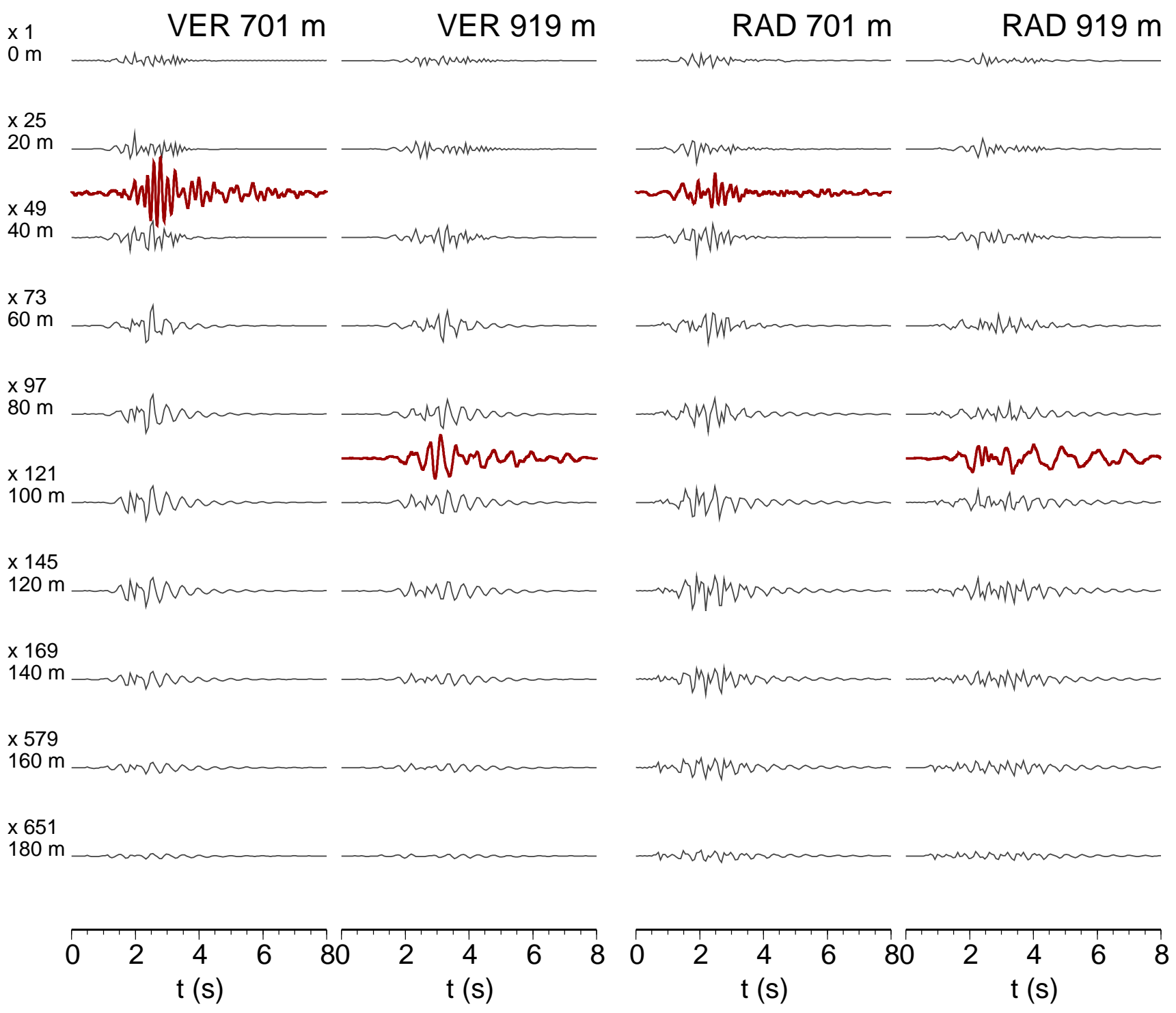

Figure 8: Synthetic waveforms (gray lines) from a vertical linear dipole $\left(M_{z z}=-1.0\right)$ have been calculated for different depths (left label in $m$ ) and are compared for vertical and radial component to observed seismograms at station DES2. The seismograms in $701 \mathrm{~m}$ distance have been artificially excited in about $30 \mathrm{~m}$ depth from a pile driver, while the seismograms in $919 \mathrm{~m}$ distance represent the micro-earthquake in unknown depth. The micro-earthquake was 100 times larger than the artificial events and was scaled down. 

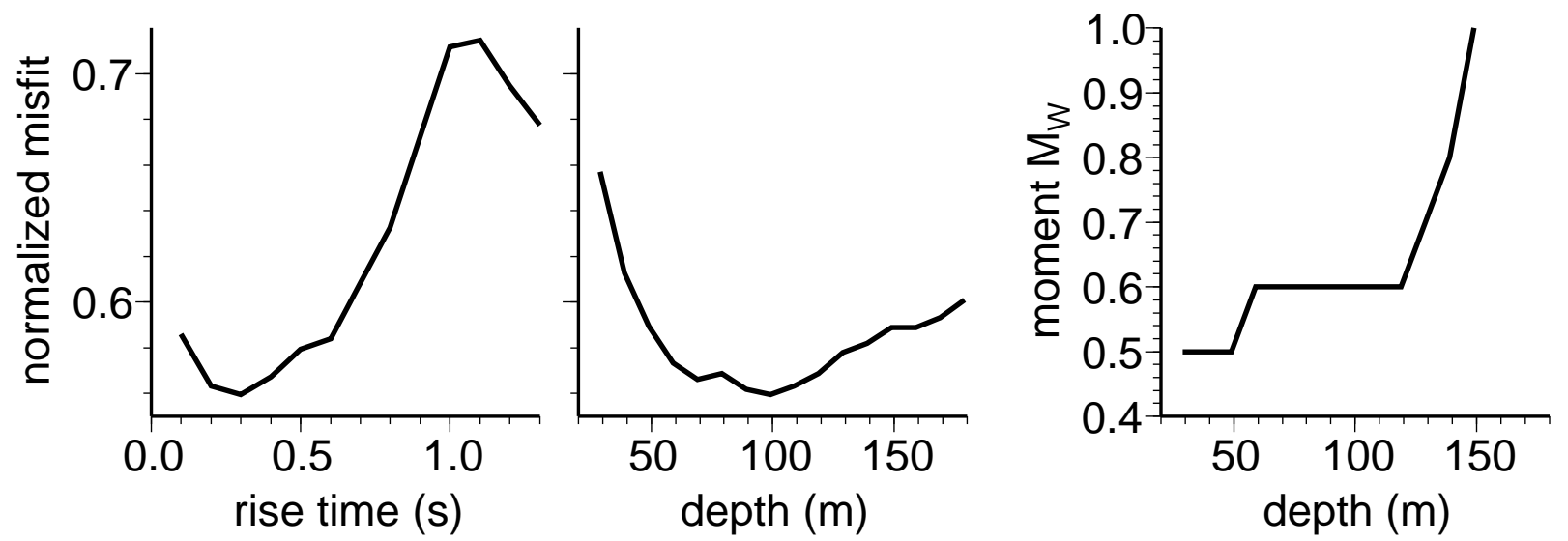

Figure 9: Result of a systematic grid search inversion based on the method of Heimann (2010). Shown are misfit versus rise time, misfit versus depth and seismic moment versus depth. Misfit is defined by the residual sum (L2 norm) of observed against theoretical grond displacement, normalized against zero traces. For each "walk" the non-constrained source parameter were left free.
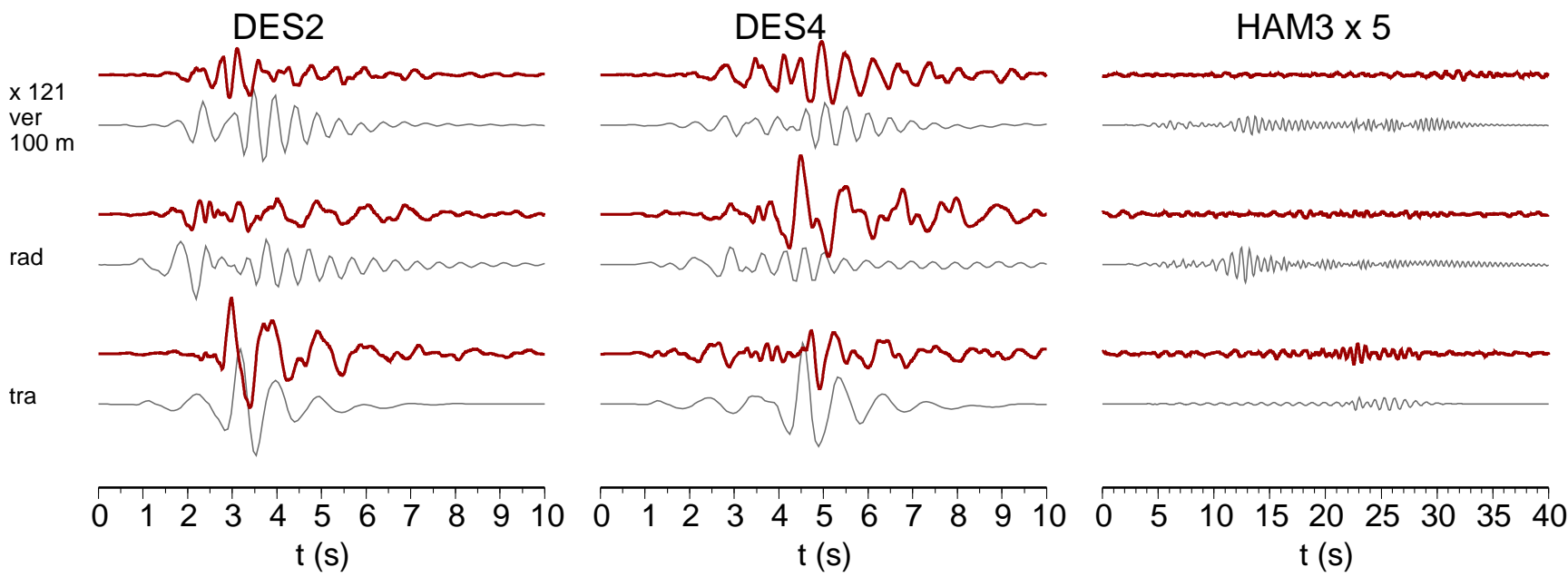

Figure 10: Synthetic waveforms, vertical component (gray) are compared to observed ground displacement (red). A smoothed ramp function of $0.3 s$ duration was used as excitation. Assuming a source depth of of $100 \mathrm{~m}$ predicts a moment magnitude of 0.6 $\left(M_{0} \approx 8.9 \cdot 10^{9} \mathrm{Nm}\right)$. The used moment tensor was $M_{y z}=6.4 \cdot 10^{9} \mathrm{Nm}, M_{z z}=-9.28$. $10^{9} \mathrm{Nm}, M_{x z}=-2 \cdot 10^{9} \mathrm{Nm}$ and $M_{x x}=M_{x y}=M_{y y}=0$, representing a vertical linear dipole and $73^{\circ}$ dipping normal fault shear crack with a strike of $17.4^{\circ}$. Waveforms have been up-scaled with increasing source depth and for station HAM3, and the scaling factors are declared by numbers. 


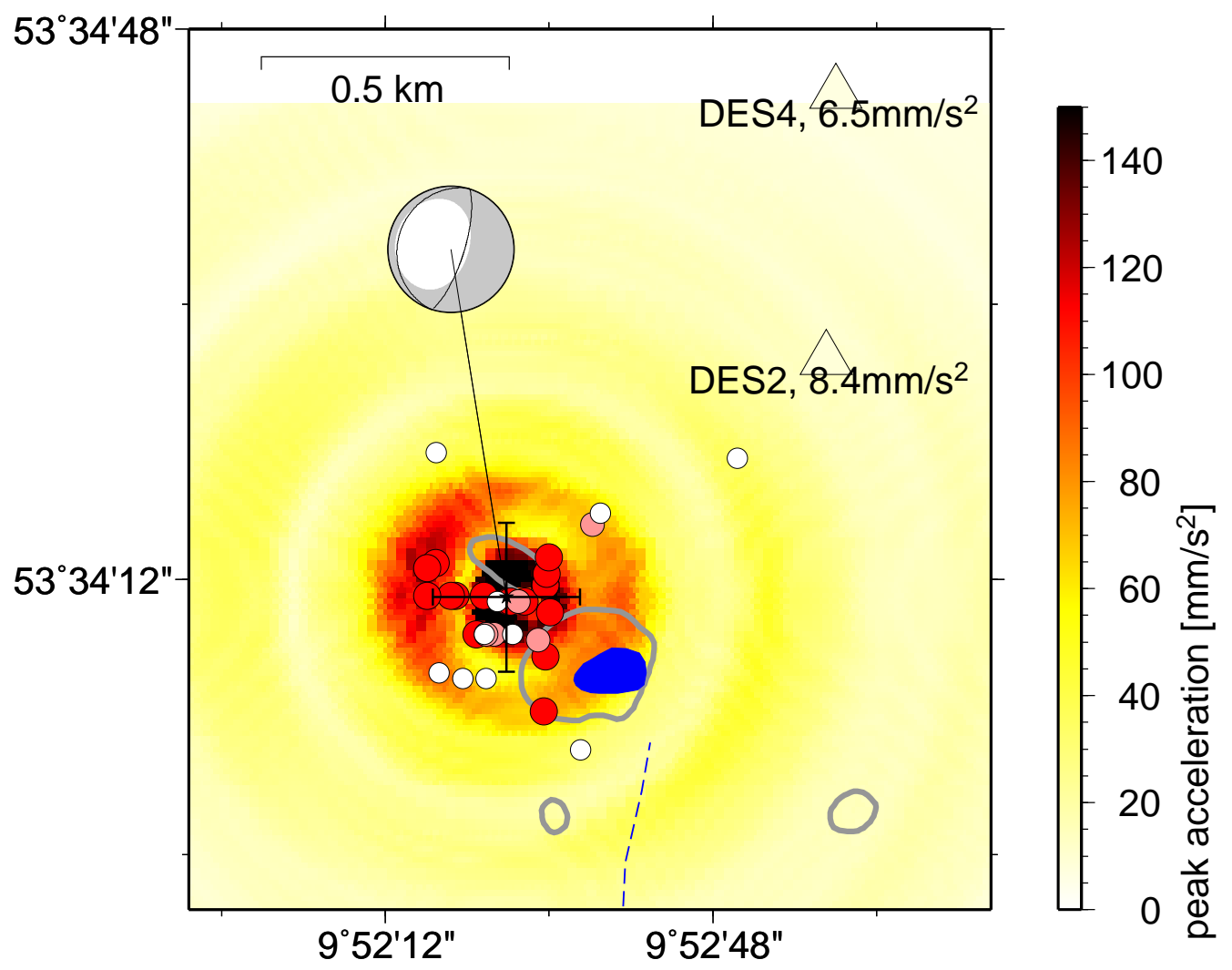

Figure 11: Theoretical (gridded) and measured peak ground acceleration at DES2 and DES4 (coloured triangles). The source was placed in $100 \mathrm{~m}$ depth and the focal solution (lower hemispherical projection) indicates the source mechanism. The frequency range of synthetic seismograms was between 0.2 and $7 \mathrm{~Hz}$, with a dominant frequency at $\approx 3.3 \mathrm{~Hz}$. The filled circles indicate locations of strong (red), moderate (light red) or no perceptibility by local inhabitants. Grey lines indicate geological documented and partly filled sinkhole features, blue polygon the Flottbek Markt Moor, and dashed line the approximate trace of the Röbbek drain (subsurface). 

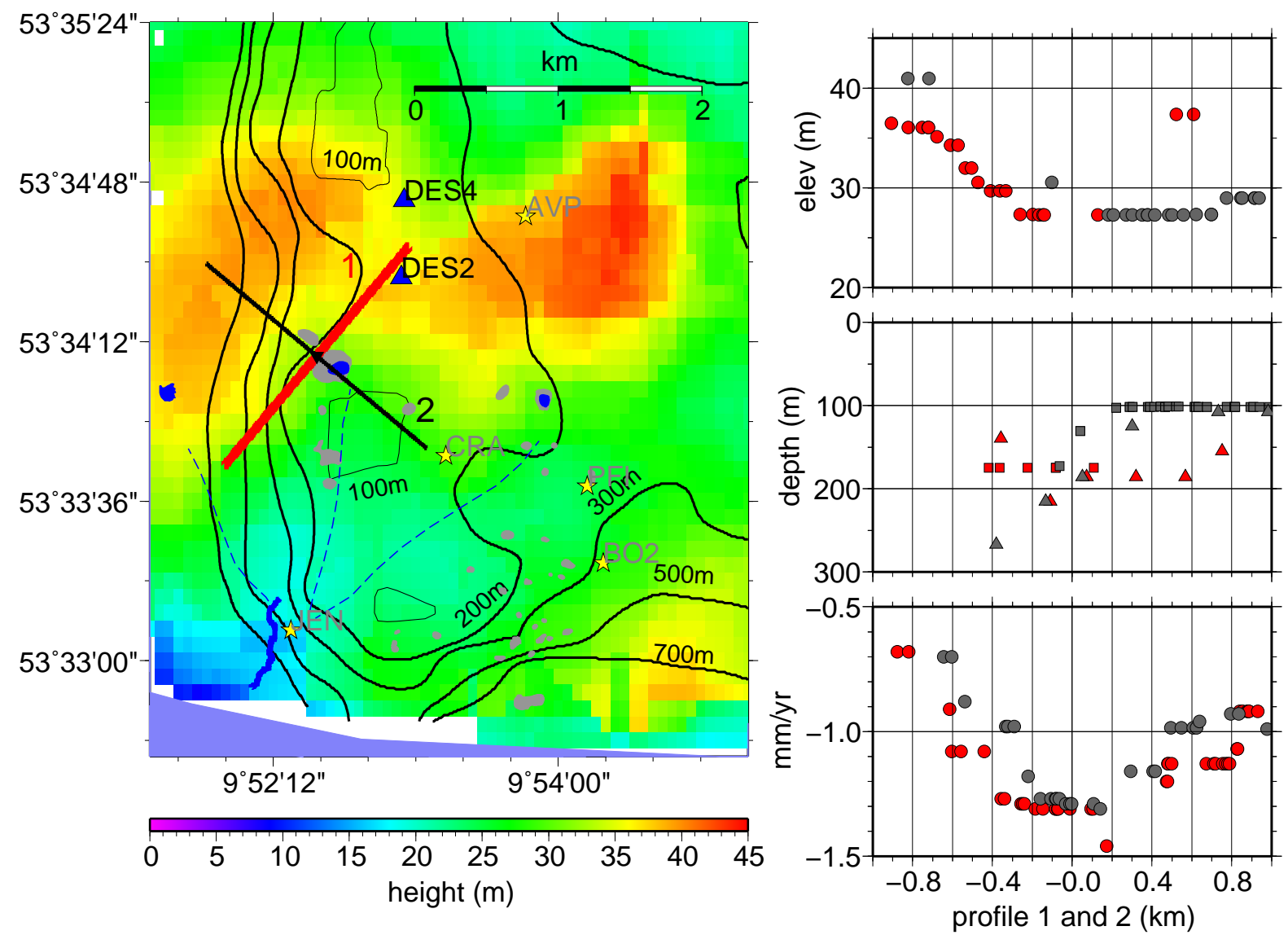

Figure 12: Left: Elevation (gridded colors) and salt top model (contourlines) in the region of felt ground shaking (filled red circles) and historic ground shaking events (open circles). Profiles 1 and 2 are indicated. Right: Elevation and salt top depth are projected from a $\pm 200 \mathrm{~m}$ wide profile-parallel stripe on profile 1 (red symbos) and 2 (black symbols). Elevation is based on repeated leveling data. The salt top model is derived from both, a 3D gravity inversion (triangles Dahm et al., 2010) and from H/V pseudo depths (filled circles Kühn et al., 2010). The cross-section on the bottom right shows the projected yearly subsidence rates as derived from persistent scatterer InSAR analysis (pers. commun. Schäffer, BGRm, see Dahm et al., 2010, for description). For both profiles $x=0$ is at the epicenter of the 2009 April events. 
I)

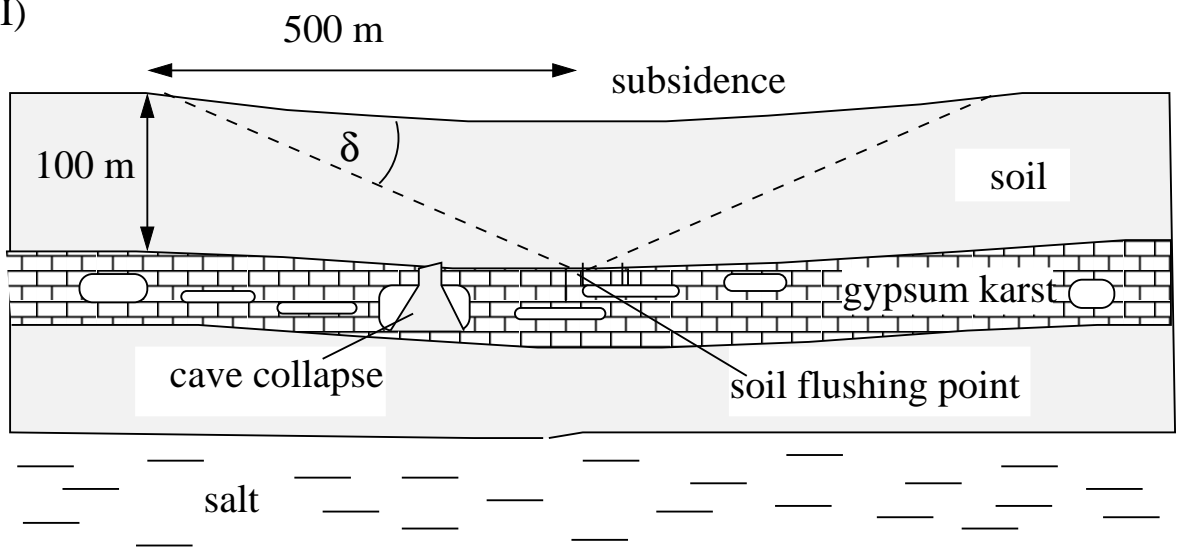

IIa)

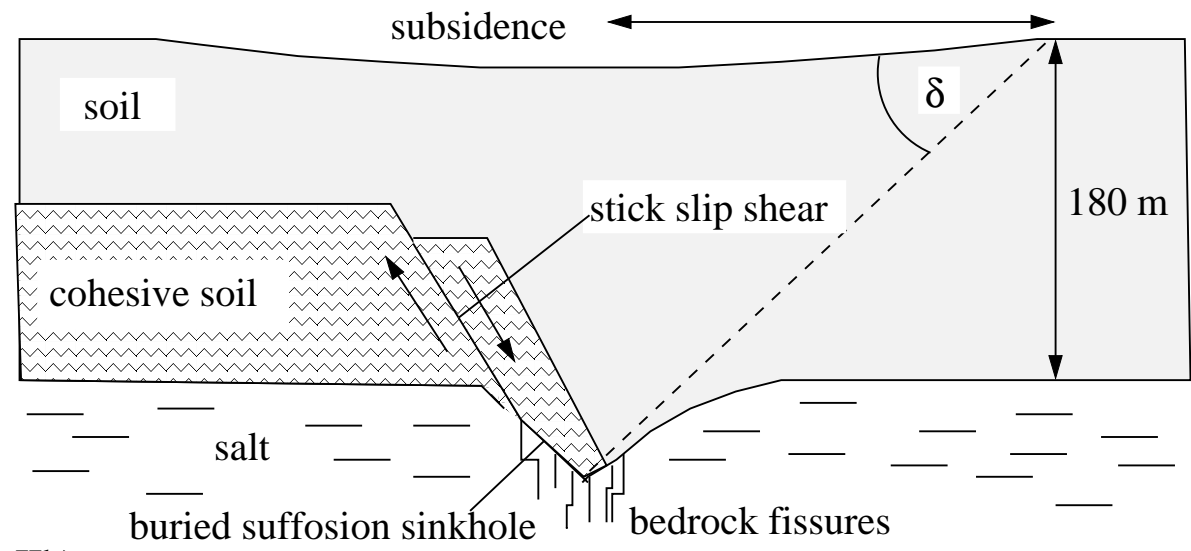

IIb)

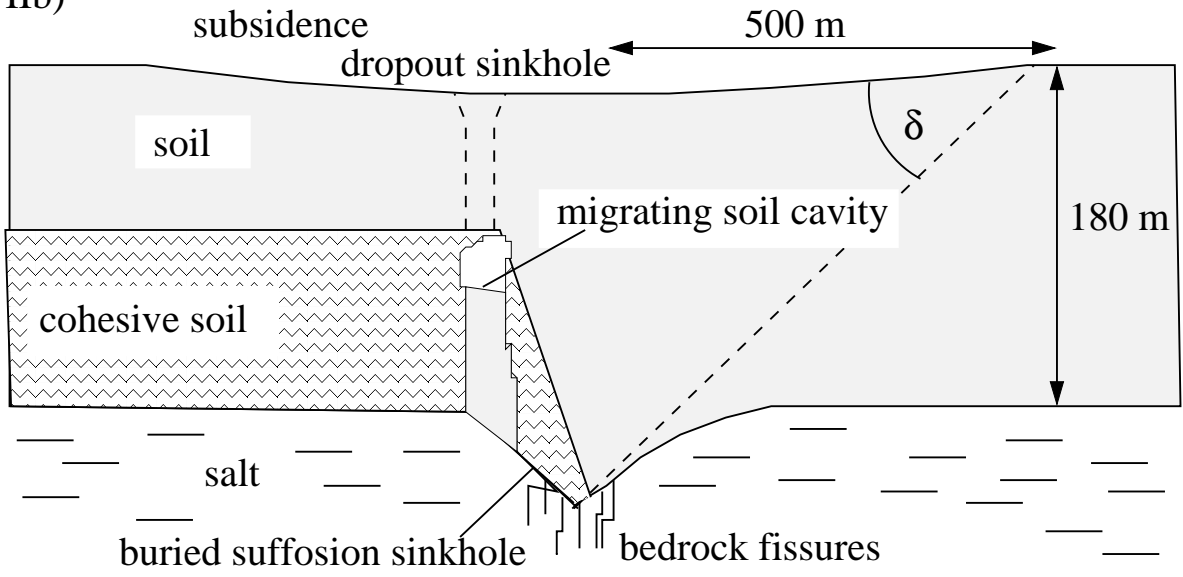

Figure 13: Conceptual micro-earthquake models: I): paleo caves in gypsum karst with cave collapse and soil flushing point of suffosion sinkhole. IIa): active salt karst with deep-seated soil flushing point. Stick slip behavior on a shear splay fault within cohesive soil is associated with co-seismic slip. IIb): same as IIa, but assuming that the rooffailure of an upward migrating soil cavity causes coseismic shocks. The dashed line indicates the shear horizont of an idealized suffosion-controlled subsidence cone. 


\section{Appendix A: Summary of historical ground shocks in Hamburg}

Table 1: Summary of historical reports on unusual ground shaking in Hamburg, classified as confirmed (A) or vague (C) if original literature has not been available to the authors. References: S32=Sieberg (1932); S40=Sieberg (1940); LD=Leydecker (1986, 1998); HA=Hamm (1956);

\begin{tabular}{|c|c|c|c|c|c|}
\hline date & epicenter & Int. & \multicolumn{2}{|c|}{ clapsobservation } & reference \\
\hline 22.01 .1760 & G. Flottbek & & $\mathrm{C}$ & $\begin{array}{l}\text { shortly mentioned together with a shaking event in } \\
\text { Kopenhagen, location is unclear, but gives reference } \\
\text { to Lersch, 19-volume handwriting }\end{array}$ & $\mathrm{S} 32, \mathrm{~S} 40$ \\
\hline 08.08 .1771 & Hamburg & IV & $\mathrm{A}$ & & $\mathrm{S} 40, \mathrm{LD}$ \\
\hline 24.01 .1834 & Hamburg & & $\mathrm{C}$ & unknwon & \\
\hline 1896 & G. Flottbek & & $\mathrm{C}$ & & Koch (1938) \\
\hline 07.11 .1898 & Hamburg & & $\mathrm{C}$ & unknown & \\
\hline 1903 & G. Flottbek & & $\mathrm{C}$ & & Koch (1938) \\
\hline 07.12 .1904 & Hamburg & II-III & C & & $\begin{array}{ll}\text { LD, } & \text { Grube } \\
(1970) & \\
\end{array}$ \\
\hline 16.01 .1907 & Hamburg & III & $\mathrm{C}$ & & $\begin{array}{ll}\text { LD, } & \text { Grube } \\
(1970) & \\
\end{array}$ \\
\hline 1912 & G. Flottbek & & $\mathrm{C}$ & & Koch (1938) \\
\hline $1914-18$ & G. Flottbek & & $\mathrm{C}$ & & Koch (1938) \\
\hline $1918-21$ & G. Flottbek & & $\mathrm{C}$ & & Koch (1938) \\
\hline 1928 & & & $\mathrm{C}$ & & Quelle unklar \\
\hline 29.09 .1929 & $\begin{array}{l}\text { G. Flottbek, } \\
\text { Wobbe See }\end{array}$ & VI & A & $\begin{array}{l}\text { about } 150 \text { buildings affected; windos rattled; furniture } \\
\text { librated; no structural damage, perceptibility radius } \\
\text { about } 1 / 3 \mathrm{~km}^{2}\end{array}$ & $\begin{array}{l}\text { S32, HA, LD, } \\
\text { Grube (1974), } \\
\text { Koch (1938), } \\
\text { Hamburger } \\
\text { Nachrichten }\end{array}$ \\
\hline 06.10 .1929 & $\begin{array}{l}\text { G. Flottbek, } \\
\text { Wobbe See }\end{array}$ & weak & $\mathrm{A}$ & weak ground shock & $\begin{array}{l}\text { Koch (1938), } \\
\text { Grube (1974) }\end{array}$ \\
\hline 09.12 .1930 & & & $\mathrm{C}$ & & source unknown \\
\hline 10.04 .1935 & & & $\mathrm{C}$ & & source unknown \\
\hline $\begin{array}{l}1936 \text { oder } \\
1937\end{array}$ & & & $\mathrm{C}$ & & source unknown \\
\hline 07.01 .1938 & \begin{tabular}{lr} 
G. & Flottbek, \\
crossing Osdor- \\
fer & Landstraße \\
$/$ & Seestraße \\
and & Wobbe \\
See, & north- \\
ern part of \\
\multicolumn{2}{l}{ Seestraße } \\
\end{tabular} & & $\mathrm{A}$ & $\begin{array}{l}\text { weak ground shock; fallen furnitures; crack formation } \\
\text { in walls; weakest damage, airless rumpling and snap- } \\
\text { ing; perceptible in about } 1.5 \mathrm{~km}^{2}\end{array}$ & $\begin{array}{l}\text { HA, LD, } \\
\text { Koch (1938), } \\
\text { Schmidt (1963), } \\
\text { Grube (1974), } \\
\text { Hamburger } \\
\text { Nachrichten, } \\
\text { Nöring. }\end{array}$ \\
\hline 1947 & & & $\mathrm{C}$ & & Grube (1974) \\
\hline 1955 & & & $\mathrm{C}$ & & Grube (1974) \\
\hline 19.03 .1960 & $\begin{array}{l}\text { G. Flottbek, } \\
\text { perceptibility } \\
\text { at least as large } \\
\text { as in } 1963\end{array}$ & strong & $\mathrm{A}$ & $\begin{array}{l}\text { strong shaking and crushing; long lasting, strong os- } \\
\text { cillations, falling pictures; cracks in ceiling; electrical } \\
\text { power failure; reported subsidence of the market (Os- } \\
\text { dorfer Landstrae) of } 0.5 \text { to } 1 \mathrm{~m}\end{array}$ & source unknown \\
\hline 1961 & & & $\mathrm{C}$ & & source unknown \\
\hline
\end{tabular}




\begin{tabular}{|c|c|c|c|c|c|}
\hline 30.01 .1963 & $\begin{array}{l}\text { G. Flottbek, } \\
\text { crossing Osdor- } \\
\text { fer Landstraße } \\
\text { / Seestrae }\end{array}$ & $\begin{array}{l}\text { weak, } \\
\text { ground } \\
\text { accel- } \\
\text { era- } \\
\text { tion } \\
3-5 \\
\mathrm{~cm} / \mathrm{s}^{2}\end{array}$ & A & $\begin{array}{l}\text { weak and silent ground shaking; deep irumbling, shak- } \\
\text { ing houses }\end{array}$ & $\begin{array}{l}\text { Schmidt (1963), } \\
\text { Grube (1974) }\end{array}$ \\
\hline 08.04 .2000 & $\begin{array}{l}\text { G. Flottbek, } \\
\text { area of Notkes- } \\
\text { See- and } \\
\text { Windmühlen- } \\
\text { straße }\end{array}$ & IV & A & strong shaking, explosion like sound, rattling dishes & $\begin{array}{l}\text { Taugs, Geol. } \\
\text { Landesamt } \\
\text { Hamburg } \\
(2000)\end{array}$ \\
\hline 08.04 .2009 & $\begin{array}{l}\text { G. Flottbek, } \\
\text { Staudingerstr., } \\
\text { Wohlsteinkamp, } \\
\text { Viereck }\end{array}$ & III & A & $\begin{array}{l}\text { weak ground motion, Knall, first aftershock } 1 \mathrm{~h} \text { after } \\
\text { main event }\end{array}$ & $\begin{array}{l}\text { own measure- } \\
\text { ments }\end{array}$ \\
\hline 28.04 .2009 & $\begin{array}{l}\text { G. Flottbek, } \\
\text { Staudingerstr., } \\
\text { Wohlsteinkamp, } \\
\text { Viereck }\end{array}$ & weak & A & weak ground motion & $\begin{array}{l}\text { own measure- } \\
\text { ments }\end{array}$ \\
\hline
\end{tabular}




\section{Appendix B: Drift correction station DES4}

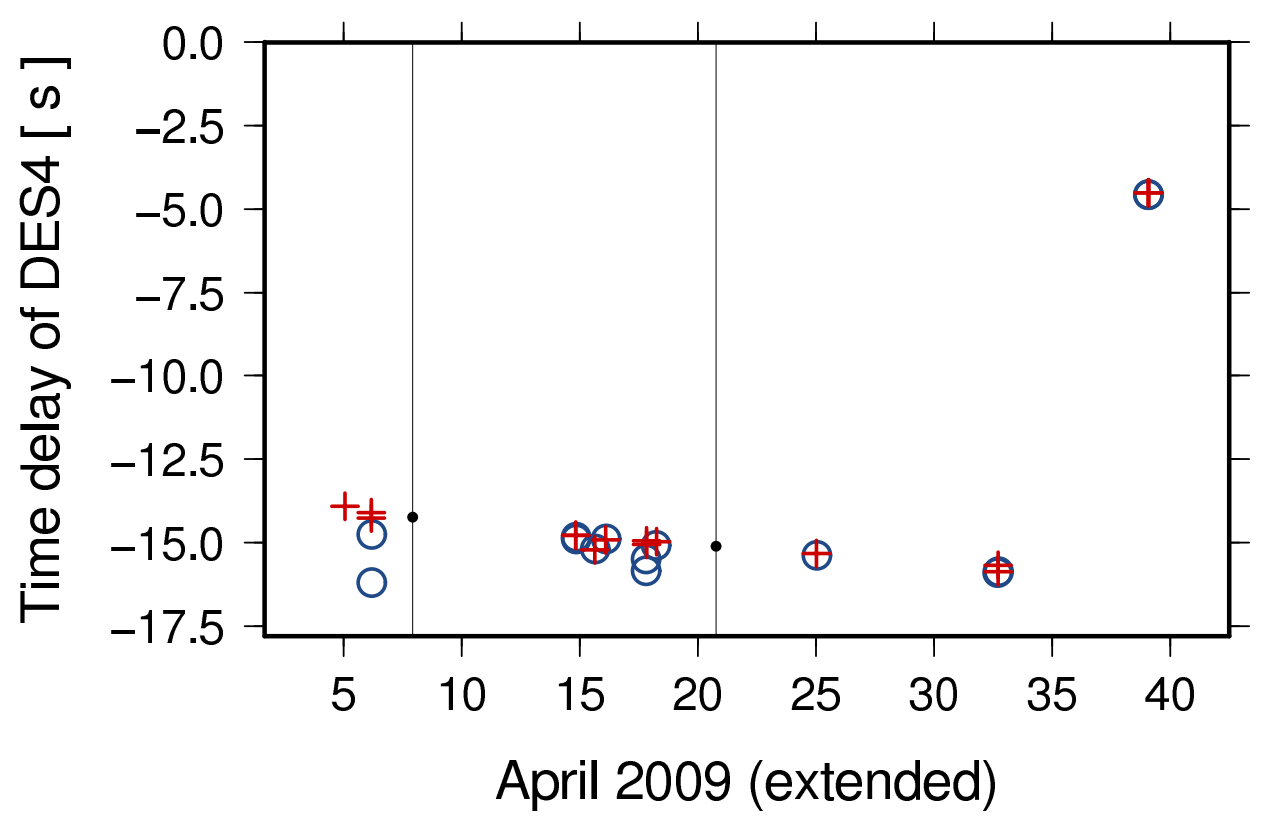

Figure B.1: Time shift and drift of station DES4, as derived from cross-correlating body wave phases of 10 different teleseismic earthquakes. Pn, P, and PP phases (red crosses), as well as Sn, S, and SS phases (blue circles) have been used (where observable, respectively). The vertical black lines mark the times of the 8 April and 21 April 2009 local events, where the corresponding time shift can be estimated (by eye) as -14.25 $s$ and -15.1 $s$ (black dots). The theoretical travel time difference for phase arrivals at the two stations was less than $0.07 \mathrm{~s}$ for all investigated phases, and has been neglected in the computation. The seismograms were filtered between 0.01 and $0.5 \mathrm{~Hz}$ before calculating the cross correlation. Time windows of $60 s$ length have been used. 


\section{Electronic supplement of Table A: original description of felt reports}

Table 2: Zusammenfassung der historischen Berichte $\mathrm{zu}$ ungewöhnlichen Erschütterungen in Hamburg. Klassifizierung in Kategorie (Kat.) verlässlich (A) oder vage (C) falls keine Originalliteratur zur Verfügung stand. Referenzen: S32=Sieberg (1932); S40=Sieberg (1940); LD=Leydecker (1986, 1998); HA=Hamm (1956);

\begin{tabular}{|c|c|c|c|c|c|}
\hline Datum & Epizentrum & Int. & $\mathrm{Ka}$ & Beobachtung & Referenz \\
\hline 22.01 .1760 & G. Flottbek & & $\mathrm{C}$ & $\begin{array}{l}\text { kurz erwähnt zusammen mit Erschütterungen in } \\
\text { Kopenhagen, Lokation is unklar. Referenz auf Lersch, } \\
\text { 19-bändige Handschrift }\end{array}$ & $\mathrm{S} 32, \mathrm{~S} 40$ \\
\hline 08.08 .1771 & Hamburg & IV & $\mathrm{A}$ & & $\mathrm{S} 40, \mathrm{LD}$ \\
\hline 24.01 .1834 & Hamburg & & $\mathrm{C}$ & Quelle unklar & \\
\hline 1896 & G. Flottbek & & $\mathrm{C}$ & & Koch (1938) \\
\hline 07.11 .1898 & Hamburg & & $\mathrm{C}$ & Quelle unklar & \\
\hline 1903 & G. Flottbek & & $\mathrm{C}$ & & Koch (1938) \\
\hline 07.12 .1904 & Hamburg & II-III & $\mathrm{C}$ & & $\begin{array}{ll}\text { LD, } & \text { Grube } \\
(1970) & \end{array}$ \\
\hline 16.01 .1907 & Hamburg & III & $\mathrm{C}$ & & $\begin{array}{ll}\text { LD, } & \text { Grube } \\
(1970) & \end{array}$ \\
\hline 1912 & G. Flottbek & & $\mathrm{C}$ & & Koch (1938) \\
\hline 1914-18 & G. Flottbek & & $\mathrm{C}$ & & Koch (1938) \\
\hline $1918-21$ & G. Flottbek & & $\mathrm{C}$ & & Koch (1938) \\
\hline 1928 & & & $\mathrm{C}$ & & Quelle unklar \\
\hline 29.09 .1929 & $\begin{array}{l}\text { G. Flottbek, } \\
\text { Wobbe See }\end{array}$ & VI & $\mathrm{A}$ & $\begin{array}{l}\text { ca. } 150 \text { Häuser betroffen; Fenster klirrten; Möbel } \\
\text { schwankten; keine Gebäudeschäden, Schüttergebiet ca } \\
1 / 3 \mathrm{~km}^{2}\end{array}$ & $\begin{array}{l}\text { S32, HA, LD, } \\
\text { Grube (1974), } \\
\text { Koch (1938), } \\
\text { Hamburger } \\
\text { Nachrichten }\end{array}$ \\
\hline 06.10 .1929 & $\begin{array}{l}\text { G. Flottbek, } \\
\text { Wobbe See }\end{array}$ & schwach & $\mathrm{A}$ & schwacher Erdstoß & $\begin{array}{l}\text { Koch (1938), } \\
\text { Grube (1974) }\end{array}$ \\
\hline 09.12 .1930 & & & $\mathrm{C}$ & & Quelle unklar \\
\hline 10.04 .1935 & & & $\mathrm{C}$ & & Quelle unklar \\
\hline $\begin{array}{l}1936 \text { oder } \\
1937\end{array}$ & & & $\mathrm{C}$ & & Quelle unklar \\
\hline 07.01 .1938 & $\begin{array}{l}\text { G. Flottbek, } \\
\text { Kreuzung } \\
\text { Osdorfer } \\
\text { Landstraße / } \\
\text { Seestraße und } \\
\text { Wobbe See im } \\
\text { Norden der } \\
\text { Seestraße }\end{array}$ & & $\mathrm{A}$ & $\begin{array}{l}\text { schwacher Erdstoß; umgestürzte Möbel; klaffende } \\
\text { Risse im Mauerwerk; schwächste Schäden, dumpfes } \\
\text { Grollen und Knallen; ca. } 1.5 \mathrm{~km}^{2} \text { gespürt }\end{array}$ & $\begin{array}{l}\text { HA, LD, } \\
\text { Koch (1938), } \\
\text { Schmidt (1963), } \\
\text { Grube (1974), } \\
\text { Hamburger } \\
\text { Nachrichten, } \\
\text { Nöring. }\end{array}$ \\
\hline 1947 & & & $\mathrm{C}$ & & Grube (1974) \\
\hline 1955 & & & $\mathrm{C}$ & & Grube (1974) \\
\hline 19.03 .1960 & $\begin{array}{l}\text { G. Flottbek, } \\
\text { erfasste mind. } \\
\text { das ganze } \\
\text { Gebiet der } \\
\text { Erschütterung } \\
\text { von } 1963\end{array}$ & stark & $\mathrm{A}$ & $\begin{array}{l}\text { stärkere Erschütterungen und Stösse; lang anhaltende, } \\
\text { stärkere Schwingung, weitschwingende Stöße; herun- } \\
\text { terfallende Bilder; Risse in den Decken; Verlöschen des } \\
\text { elektrischen Lichtes; angebliche Senkung des Wochen- } \\
\text { marktes in der Osdorfer Landstrae (Epizentrum) um } \\
0.5 \text { bis } 1 \mathrm{~m}\end{array}$ & Quelle unklar \\
\hline 1961 & & & $\mathrm{C}$ & & Quelle unklar \\
\hline
\end{tabular}




\begin{tabular}{|c|c|c|c|c|c|}
\hline 30.01 .1963 & $\begin{array}{l}\text { G. Flottbek, } \\
\text { Kreuzung } \\
\text { Osdorfer } \\
\text { Landstraße / } \\
\text { Seestrae } \\
\end{array}$ & $\begin{array}{l}\text { schwach, } \\
\text { Beschl. } \\
3-5 \\
\mathrm{~cm} / \mathrm{s}^{2}\end{array}$ & $\mathrm{~A}$ & $\begin{array}{l}\text { leichte Erdstöße; fast ohne Geräusch, tieferes Poltern, } \\
\text { Schwanken und Schaukeln der Häuser }\end{array}$ & $\begin{array}{l}\text { Schmidt (1963), } \\
\text { Grube (1974) }\end{array}$ \\
\hline 08.04 .2000 & $\begin{array}{lr}\text { G. } & \text { Flot- } \\
\text { tbek, Bereich } \\
\text { Notkes-, See- } \\
\text { und } \quad \text { Wind- } \\
\text { mühlenstraße }\end{array}$ & IV & $\bar{A}$ & $\begin{array}{l}\text { starke Erschütterungen, explosionsartige Geräusche, } \\
\text { Geschirr klirrte }\end{array}$ & $\begin{array}{l}\text { Taugs, Geol. } \\
\text { Landesamt } \\
\text { Hamburg } \\
(2000)\end{array}$ \\
\hline 08.04 .2009 & $\begin{array}{l}\text { G. Flottbek, } \\
\text { Staudingerstr., } \\
\text { Wohlsteinkamp, } \\
\text { Viereck }\end{array}$ & III & $\mathrm{A}$ & $\begin{array}{l}\text { schwache Erschütterungen, Knall, Nachbeben ca } 1 \mathrm{~h} \\
\text { nach Hauptbeben }\end{array}$ & eig. Messungen \\
\hline 28.04 .2009 & $\begin{array}{l}\text { G. Flottbek, } \\
\text { Staudingerstr., } \\
\text { Wohlsteinkamp, } \\
\text { Viereck }\end{array}$ & schwach & A & schwache Erschütterungen & eig. Messungen \\
\hline
\end{tabular}

